\title{
THE HALOPHYTIC VEGETATION IN SOUTH-EAST BULGARIA AND ALONG THE BLACK SEA COAST
}

\author{
Rossen TZONEV ${ }^{1}$, Tatiana LYSENKO${ }^{2}$, Chavdar GUSSEV ${ }^{3}$, Petar ZHELEV ${ }^{4}$
}

\begin{abstract}
The paper presents results of a syntaxonomic analysis of the herbaceous phytocoenoses on the salt steppes, meadows and marshes in Southeastern Bulgaria, and along the Southern Black Sea Coast. The halophytic vegetation is distributed mostly in the Tundzha Lowland and the large salt lakes along the Black Sea Coast, where the saline soils occupy large territories. Most syntaxa identified in the paper are well-known and widespread in Central and Eastern Europe (Salicornietum prostratae, Suaedetum maritimae, Juncetum maritimae etc.), but there are also some specific vegetation types, which are presented by endemic associations as Petrosimonio brachiatae-Puccinellietum convolutae, Bupleuro tenuissimae-Camphorosmetum monspeliacae. The most widespread one is Diantho pallidiflori-Puccinellietum convolutae. It demonstrates a big variation in the appearance and the dominant structure of the described phytocoenoses. The comparision of the Bulgarian halophytic vegetation with other places in Europe shows its similarities with these vegetation types distributed in the Eastern Mediterranean and Central and Eastern Europe.

Key words: Halophytic vegetation, syntaxonomy, saline habitats, NATURA 2000, Bulgaria.

\section{Izvleček}

V članku so predstavljeni rezultati sintaksonomske analize zeliščnih fitocenoz slanih step, travišč in močvirij v jugovzhodni Bolgariji in ob južni črnomorski obali. Halofitska vegetacija je najbolj pogosta v nižini Tundzha in v velikih slanih jezerih ob obali Črnega morja, kjer slana tla zavzemajo velika območja. Večina obravnavanih sintaksonov je dobro znanih in splošno razširjenih v srednji in vzhodni Evropi (Salicornietum prostratae, Suaedetum maritimae, Juncetum maritimae itd.), nekaj pa je posebnih vegetacijskih tipov, ki jih predstavljajo endemične asociacije Petrosimonio brachiatae-Puccinellietum convolutae, Bupleuro tenuissimae-Camphorosmetum monspeliacae. Najbolj razširjena je združba, ki jo uvrščamo v asociacijo Diantho pallidiflori-Puccineltietum convolutae, za katero je značilna velika variabilnost v videzu in dominantni strukturi. Primerjava halofitske vegetacije iz Bolgarije je pokazala podobnosti z vegetacijskimi tipi, razširjenimi v vzhodnem Sredozemlju ter srednji in vzhodni Evropi.
\end{abstract}

Ključne besede: halofitska vegetacija, sintaksonomija, slanišča, NATURA 2000, Bolgarija.

\footnotetext{
${ }^{1}$ Department of Ecology and Environmental Protection, Faculty of Biology, Sofia University "St. Kliment Ohridsky", 8 Dragan Tzankov Blvd., Sofia, BG-1164, Bulgaria. E-mail: rossentzonev@abv.bg

${ }^{2}$ Department of Problems of the Phytodiversity, Institute of Ecology of the Volga River Basin, Russian Academy of Sciences, Komzin St. 10, Togliatti, Ru 445003, Russia. E-mail: ltm2000@mail.ru

${ }^{3}$ Department of Applied Botany, Institute of Botany, Bulgarian Academy of Sciences, Akad. G. Bonchev Str. 23, BG-1113 Sofia, Bulgaria. E-mail: chgussev@bio.bas.bg

${ }^{4}$ Department of Dendrology, University of Forestry, 10 Kliment Ochridsky Blvd., BG-1756 Sofia, Bulgaria. E-mail: zhelev@ltu.bg
} 


\section{INTRODUCTION}

The halophytic vegetation in Bulgaria is scarcely distributed, because its occurrence depends on the local edaphic conditions and some specific soil types. The climate and relief conditions in Bulgaria do not presuppose development of saline soils (Figure 1). According to Ninov (2002) the most widespread saline soil types in Bulgaria are Solonchaks and Solonetz, which are mostly of a secondary origin - on the places of former Fluvisols, Histosols and other soils of swampy and meadow areas. The main factor causing the formation of these soils is considered to be the water drainage. The two saline soil types mentioned above often coexist as a result of their mixed processes of origin. The salinization in Bulgaria is mostly of sulfate-chloride type. Ninov (1998) assessed the correlation between the main soil types and the vegetation and identified 7 main dominants in the vegetation on saline soils - Puccinellia convoluta, Aeluropus littoralis, Salicornia europaea, Artemisia santonicum, Crypsis aculeata, Crypsis alopecuroides and Cynodon dactylon.
The most typical regions for the halophytic vegetations are those with the optimal distribution of salt soils. They are scattered along the coast of the Black Sea and especially the big salt lakes - Atanasovsko, Mandra-Poda, Beloslav and Pomorie. The other region is the Valley of the Tundzha River and some of its small tributaries - Blatnica, Mochurica etc., and the Sazliika River - a tributary of the Maritza River. There are also some small territories with halophytic vegetation in North and Southwest Bulgaria.

Relatively detailed investigation of the halophytic vegetation in these regions was carried out only by means of the dominant method (Ganchev et al. 1971). In the cited work the halophytic vegetation has been classified by the authors in two main groups - Euhalophytic (the formations and the associations of Salicornia europaea, Suaeda maritima, Salsola soda, Puccinellia convoluta, Aeluropus littoralis, Crypsis aculeata, Statice latifolia, Camphorosma monspeliaca, C. апnиa) and non-typical Halophytic (the association and formations of Hordeum hystrix, Juncus gerardii, Polypogon monspeliensis, Atriplex

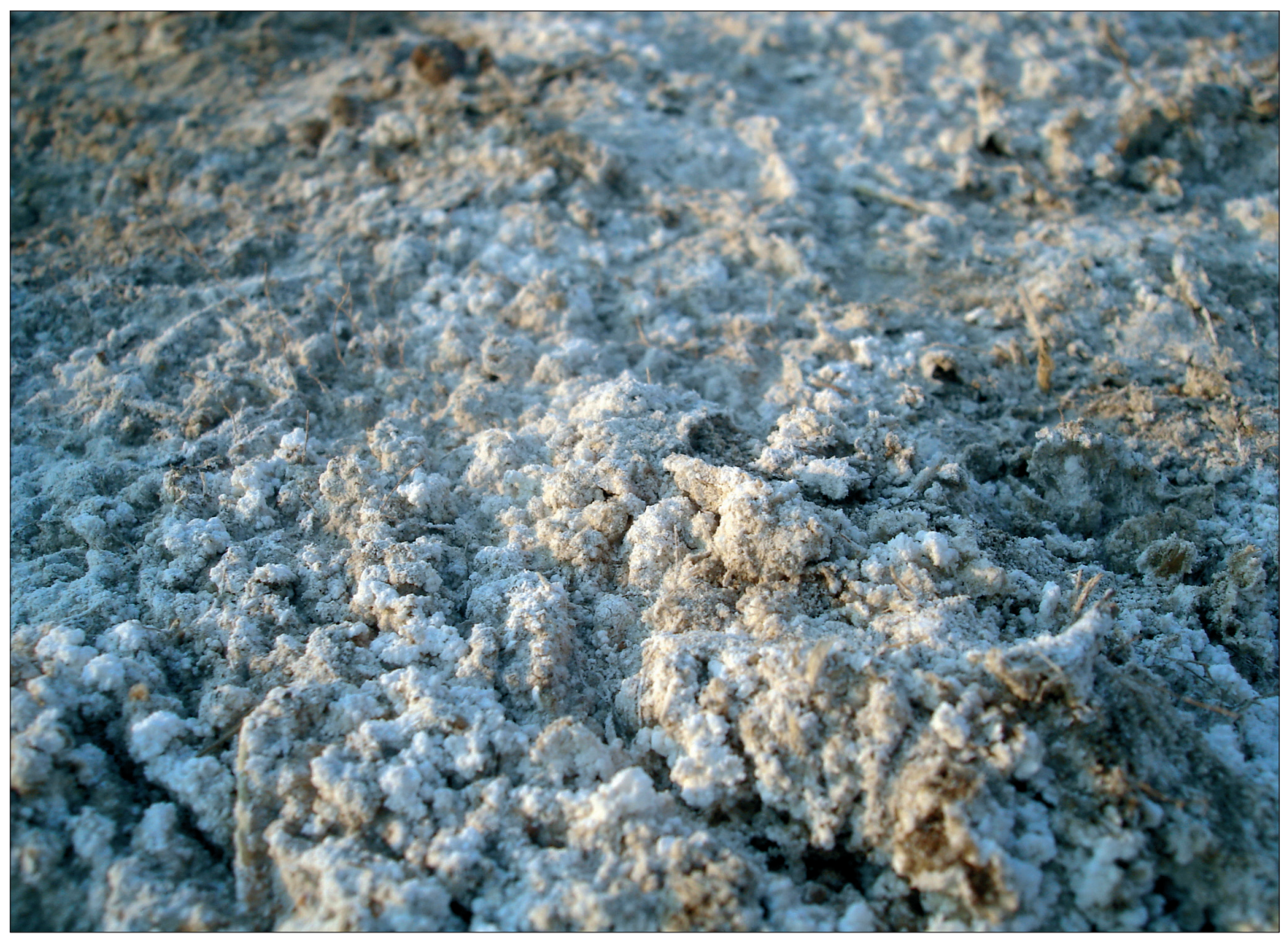

Figure 1: Typical saline soils. Slika 1: Tipična slana tla. 
hastata, Agropyron elongatum, Puccinellia distans, Juncus maritimus, Rottboellia digitata).

There are some data about this type of vegetation in the works of Yordanov (1931), Stoyanoff (1941) and Stefanoff (1943). Although they are mainly florisrtic studies, they contain information about the main vegetation types in Bulgaria including the halophytic vegetation. Ganchev \& Kochev (1962) described some halohytic communities from the Central Danubian plain by applying the dominant method. The same communities were included also in the big inventory of pastures and meadows in Bulgaria (Bondev et al. 1964). The distribution of halophytic vegetation was shown also on the map of the vegetation of Bulgaria (after the dominant method) of Bondev (1991).

The aim of this investigation is to describe and to classify the Bulgarian halophytic vegetation in the regions of their optimal distribution, according to the methodology of the Zurich-Montpellier school of phytosociology. Other purposes of the work are to analyse the relationships of the Bulgarian halophytic communities with those, which are distributed in the neighbouring territories; their contemporary status and some problems of their conservation.

\section{METHODS}

\section{Study area}

The study was performed in two regions of Bulgaria. The first region included the territory of the valleys of Tundzha and Lower Maritza rivers as well as some of their smaller tributaries. The area falls into the Thracian plain and Tundzha hilly region. The relief includes lowlands and plain areas in the river valleys, characterized predominantly by salty soils (mostly Solonetz type), which have been formed as a result of the high levels of underground waters and the strong evaporation during the long hot summers. Many of these lowlands are flooded by the spring waters of Tundzha and Maritza Rivers and their tributaries (Figure 2).

The second region was the Black Sea coast - mostly the larger hyper-saline lakes - Pomorie and Atanossovsko lakes, and only a few parts of the Beloslav Lake (Varna district - Northern Black Sea coast).

The climate in these parts of Bulgaria is of transitional type - Continental-Mediterranean (Transitional continental to Continental Mediterranean). There are some small differences concerning the
Black Sea coast, where the temperature amplitude is lower than that of the inner part of the country and the air humidity is higher, due to the sea breeze. There is a short humid period (especially in winter) and a long dry summer, but near the sea the temperature fluctuations are lower and the rainfalls are higher (Velev 1990).

\section{Sampling methods}

The phytocoenological relevés were described by R. Tzonev, Ch. Gussev and P. Zhelev during the summer of 2006; and three relevés were made by R. Tzonev and T. Lysenko during the summer of 2008, applying the methods of the sigmatic school (Braun-Blanquet 1964, Westhoff \& Maarel 1978). A total of 125 phytocoenotic relevés were made, of which 22 were rejected during the process of data analysis. Three relevés, which belong to the association Camphorosmetum annuae, were added in the tables during the finalization of this work. The expanded scale of Braun-Blanquet for abundance/ dominance (Barkman et al. 1964) was used. All phytocoenological relevés of the Bulgarian halophytic communities were accumulated in the database established with the aid of the TURBOVEG software package (Hennekens \& Schaminée 2001) and then processed with the MEGATAB visual editor for phytosociological tables (Hennekens 1996) [with the program TWINSPAN (Hill 1979) included], which is intended for hierarchical classification. TWINSPAN is a divisive polythetic program, which made a two-way analysis of the relevés on the basis of the indicator species. The final blockdiagonal table classified the relevés into 21 groups. The final tables were manually re-arranged and 12 groups remained, which are homogeneous and represent the associations or communities without syntaxonomic rank.

\section{Nomenclature}

The taxonomic nomenclature used in the paper was according to Delipavlov et al. (2003), and the syntaxonomic nomenclature followed Borhidi (2003), Dierßen (1996), Rodwell et al. (2002), Sanda et al. (1999), Pop (2002), SynBioSys Europe (http://www.synbiosys.alterra.nl/eu).

New syntaxa were described according to the rules of the International Code of Phytosociological Nomenclature (ICPN; Weber et al. 2000). 


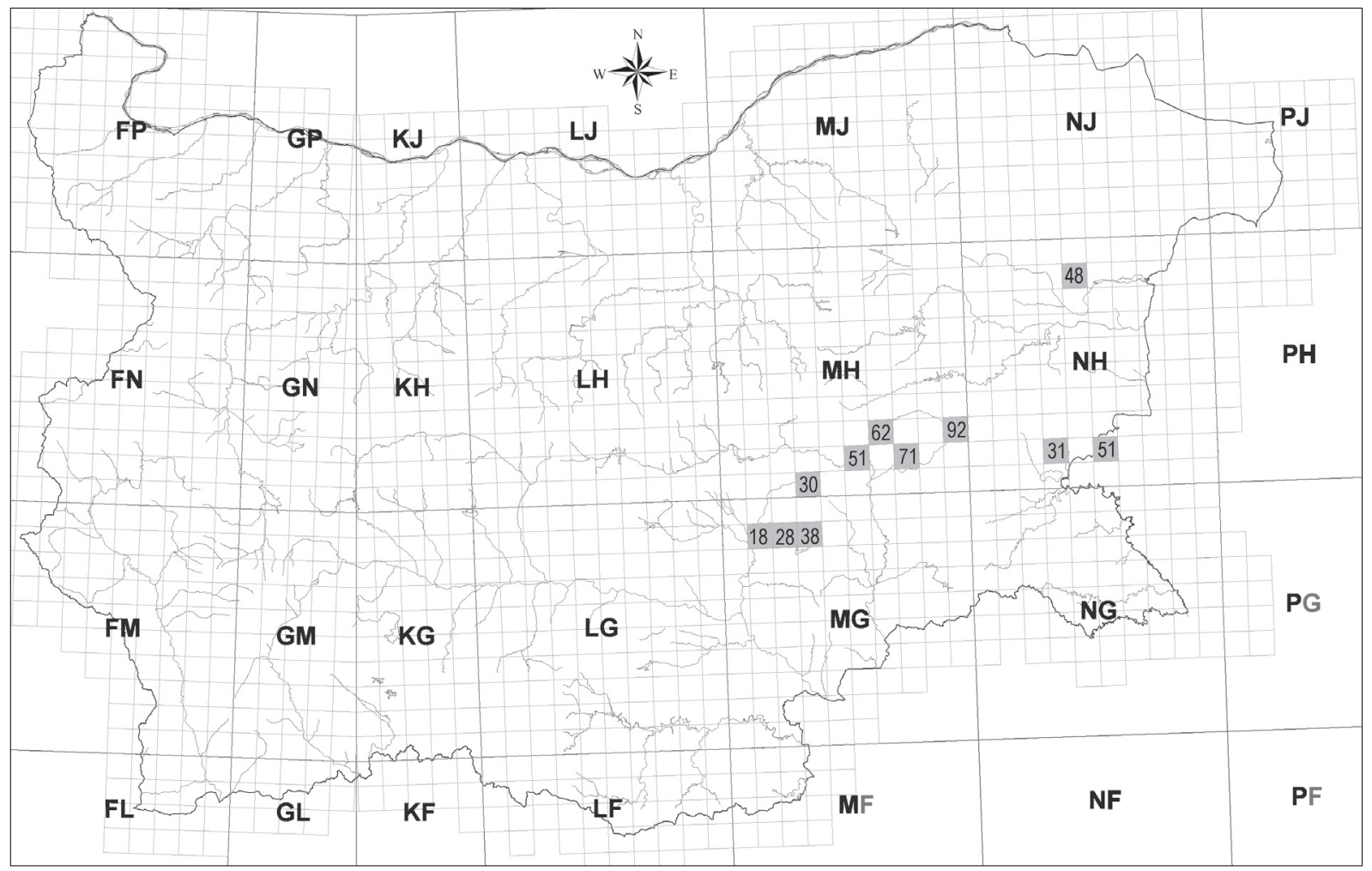

Figure 2: Map of localities with a $10 \times 10 \mathrm{~km}$ UTM grid of the investigated halophytic communities.

- Devnya town, the quarter of Povelyanovo (Varna district) - NH48;

- Pomoriisko Ezero Lake (Burgas District) - NH51;

- North from Atanasovsko ezero Rezerve - Rudnik village (Burgas district) - NH31

- Between the southern and northern part of Atanasovsko Ezero Lake - locality "Ezika" (Burgas district) - NH31;

- Sigmen village (Burgas district) - MH92;

- Trapoklovo village (Sliven district) - MH62

- Bikovo village (Sliven district) - MH30

- Zhelyu Voivoda village (Sliven district) - MH51

- Blatec village (Sliven district) - MH62

- Atolovo village (Yambol district) - MH71

- Radnevo town (Stara Zagora district) - MG18

- Kunevo village (Stara Zagora district) - MG38

- Radetzki village (Stara Zagora district) - MG28

Slika 2: Karta lokacij proučevanih halofitskih združb z UTM mrežo $10 \times 10$ km.

- mesto Devnya, četrt Povelyanovo (okrožje Varna) - NH48;

- jezero Pomoriisko Ezero (okrožje Burgas) - NH51;

- severno od rezervata Atanasovsko ezero- vas Rudnik (okrožje Burgas) - NH31

- med južnim in severnim delom jezera Atanasovsko Ezero- lokacija "Ezika" (okrožje Burgas) - NH31;

- vas Sigmen (okrožje Burgas) - MH92;

- vas Trapoklovo (okrožje Sliven) - MH62

- vas Bikovo (okrožje Sliven) - MH30

- vas Zhelyu Voivoda (okrožje Sliven) - MH51

- vas Blatec (okrožje Sliven) - MH62

- vas Atolovo (okrožje Yambol) - MH71

- mesto Radnevo (okrožje Stara Zagora) - MG18

- vas Kunevo (okrožje Stara Zagora) - MG38

- vas Radetzki (okrožje Stara Zagora) - MG28 


\section{Results and discussion}

According to our observations, the halophytic vegetation in Bulgaria is subdivided into two main types. The first one - whose communities are dominated by facultative halophytes, such as Cynodon dactylon, Juncus gerardii, Trifolium fragiferum subsp. bonannii, Cerastium dubium, Myosurus minimus, and Mentha pulegium, belongs to the class Plantaginetea majoris. Of this group, Tzonev (in press) identified in Bulgaria the association Trifolio fragiferi-Cynodontetum Br.-Bl. \& Bolòs 1958 in some former floodplains of the Danube (Belene and Tutrakan), but there are some additional observations, which demonstrate that it is widespread in the river lowlands and along the big rivers, especially the Danube and some of its tributaries - Osam, Jantra, and Vit. The floristic structure of the communities of this association is rich in synanthropic plant species.

The second group of communities belongs to the typical halophytic classes Thero-Salicornietea, Juncetea maritimae, and Festuco-Puccinellietea. They are rich in obligate halophytes as Salicornia europaea, Suaeda maritima, Camphorosma monspeliaca, Bassia hirsuta, Crypsis aculeata, Aster tripolium, Artemisia santonicum etc. The typical halophytic communities are very rare in the inner part of Northern Bulgaria. Some phytocoenoses were described by Tzonev (2002) from the Karaboaz Floodplain (Pleven district) and the Valley of the Studena River (Veliko Tarnovo district), including the associations Salicornietum prostratae, Hordeetum hystricis and Limonietum bulgaricum.

After the TWINSPAN analysis of the halophytic vegetation in Southeast Bulgaria and the Black Sea Coast, and the processing of the obtained 21 groups, the following syntaxa were established:

Class Thero-Salicornietea Tx. in Tx. et Obertd. 1958

Order Thero-Salicornietalia Pignatti 1953

Alliance Thero-Salicornion Br.-Bl. 1933

Association Salicornietum prostratae Soó (1947) 1964

Association Suaedetum maritimae Soó 1927

Association Suaedo-Bassietum hirsutae Br.-Bl. 1928

Class Juncetea maritimae $\mathrm{Br}$.-Bl. in Br.-Bl. et al. 1952

Order Juncetalia maritimae Br.-Bl. ex Horvatić 1934

Alliance Juncion maritimae Br.-Bl. ex Horvatić 1934

Association Juncetum maritimi (Rübel 1930)

Pignatti 1953

Class Isoëto-Nanojuncetea Br.-Bl. et Tx. ex Br.-Bl. et al. 1952
Order Crypsidetalia aculeatae Vicherek 1973

Alliance Cypero-Spergularion salinae Slavnic 948

Association Crypsidetum aculeatae Wenzel 1934 em. Mucina 1993

Association Heleochloetum alopecuroidis Rapaics et Ubriszy 1948

Class Festuco-Puccinellietea Soó 1968

Order Puccinellietalia Soó 1947

Alliance Puccinellion limosae Soó 1933

Association Diantho pallidiflori-Puccinellietum convolutae ass. nova hoc loco, holotypus relevé No. 4, Table 3

Association Aeluropetum littoralis (Prodan 1939) Şerbănescu 1965

Association Bupleuro tenuissimae-Camphorosmetum monspeliacae ass. nova hoc loco, holotypus relevé No. 41, Table 4

Association Camsphorosmetum annuae Rapaics ex Soó 1933

Association Petrosimono brachyatae-Puccinellietum convolutae ass. nova hoc loco, holotypus relevé No. 62, Table 2

Artemisia santonicum comm.

\section{Ass. Salicornietum prostratae Soó (1947) 1964}

This association (Table 1) was described for the first time in Bulgaria by Tzonev (2002). It occurs in the Central Danubian Plain, it isolated and the only one in the inner part of the country. It is localised in the biggest former floodplain of the Danube - Karaboaz. It should be noted that this locality does not have connections with the remaining, relatively numerous localities of Salicornia prostrata and respectively with its association along the Black Sea coast (see Ganchev et al. 1971). Its origin probably derives from the localities along the Danube in Romania, Serbia (Banat) and Hungary (Hungarian Puszta), since there is a high similarity between the characteristics of these localities and those of the Bulgaria.

The presented relevés in this study belong to the coastal localities of the species and the syntaxon. The relevés were done in the following localities - the two big hyper-saline lakes along the Bulgarian Black Sea coast - Atanassovsko and Pomoriisko - as well as in the westernmost part of Beloslav Lake (the quarter Povelyanovo of Devnya town) and Varna Lake (Kazashko locality).

There were only a few localities (Ganchev et al. 1971) that were not included in our study: Chengene skele Bay the mouth of Ropotamo River, the 
region of Mandra-Poda and the small localities along Vaya Lake. The northernmost two localities are on the shore of Balchik Touzla (a small hypersaline lagoon near the town of Balchik) and Shablenska Touzla Lake (Dobrich district).

The phytocoenoses (Figure 3) of the association's optimum are situated on the drying bottoms of the hyper-saline Black Sea Lakes - especially Pomoriisko and Atanassovsko. The water bodies are $0.20-0.40 \mathrm{~m}$ deep; the salinity is normally near 50-60 \%o. These bottoms are covered by muddyclay and in some places by muddy-sandy substrates. When the bottoms dry, they are covered by big colonies of Cyanophyta as Lyngbya spp., Phormidium spp., Rhzioclonium spp., Spirulina spp., Microcoleus chtonoplastes etc. They stay on the dry bottoms as a thick cracked crust. The coenoses dominated by Salicornia europaea (V), are temporary ones. The seasonal optimum of their development is the end of the summer and the beginning of the autumn. They are typical monocoenoses, with other species participating like Suaeda maritima (IV), Aster tripolium (III), and Puccinellia convolut (IV).

\section{Ass. Suaedetum maritimae Soó 1927}

Suaeda maritima participates as a species, in many different halophytic communities. But the relevés belonging to the association Suaedetum maritimae (Table 1) were recorded only in the northern vicinities of Atanassovsko Lake. The soils are of Meadow's Solonetz (Mollic Solonetz) types that are flooded in the spring and in the beginning of the summer. The underground waters are very rich in sodium-sulfate salts. The phytocoenoses of the association develop on large, very dry at the end of the summer, bare, very salty spots. The dominant species - Suaeda maritima is accompanied by Puccinellia convoluta, Artemisia santonicum, Cynodon dactylon, and Spergularia media. The total cover is relatively high $-90-100 \%$.

The mono-dominant communities of Suaeda maritima were characterized as having limited distribution in Bulgaria by Ganchev et al. (1971). Only two phytocoenoses with the total size of 12 decares were described near Radnevo (Stara Zagora district) and Pomorie (Burgas district).

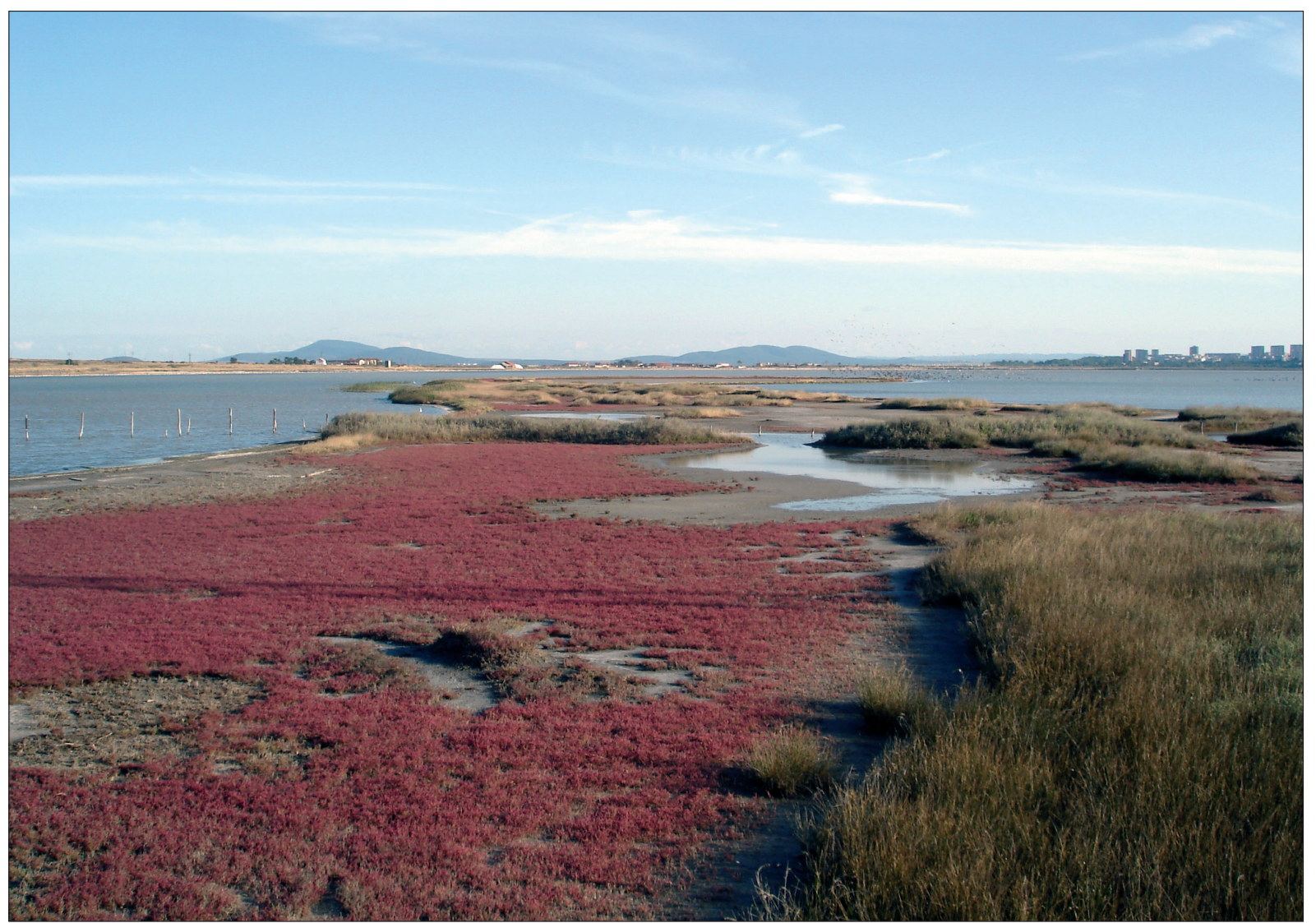

Figure 3: The association Salicornietum europeae and Juncetum maritimae in Atanassovsko Lake near Burgas. Slika 3: Asociaciji Salicornietum europeae in Juncetum maritimae ob jezeru Atanassovsko v bližini Burgasa. 
The new association Suadetem maritimae balcanicum was described by Micevski (1965) from Macedonia (former Yugoslavia). He noticed that the same syntaxon was distributed also in Bulgaria. Micevski (1965) described the new association only on the basis of 6 relevés with 4 species. According to article 34 of ICPN this association is invalid, because it was characterized only by the geographical epithet balcanicum. Of the two species with diagnostic importance - Puccinellia convoluta and Hordeum marinum (however, not indicated explicitly by the author) - only the first one was presented in the Bulgarian phytocoenoses. Also, Cynodon dactylon and Spergularia media participated in the described Bulgarian communities of Suaeda maritima, which were richer in species than the Macedonian ones. The association mentioned by Micevski (1965) Suaedetum pannonicae Wend. 1973 from Vojvodina (Serbia) was later considered by Dajić (1996) as a subassociation of the association Puccinellietum limosae. More realistic is the second possible suggestion of Micevski (1965), to accept one large association Suaedetum maritimae (poor in species) with a range of distribution connecting the Balkan Peninsula and Central Europe. We accepted this possible decision, but the question about the different subspecies of Suaeda maritima on the Balkan Peninsula - Suaeda maritima subsp. maritima, and Central Europe (including Serbia) - Suaeda maritima subsp. pannonica is still open. Probably, this taxonomical difference could have some syntaxonomical treatment in the future.

\section{Ass. Suaedo-Bassietum hirsutae Br.-B1. 1928}

This association (Table 1) is considered to be distributed in the Mediterranean region (Braun-Blanquet 1951), but according to Pott (1997) it is widespread in the Continental as well as in the Mediterranean coastal regions of Europe. This nitrophilous syntaxon is mentioned for the Black Sea coast for the first time by Ţopa (1939) and after that by Géhu et al. (1994). It is known also from the coastal zone of Greece (Babalonas et al. 1995). It is localized in the basins of Atanassovsko and Pomoiisko Lakes

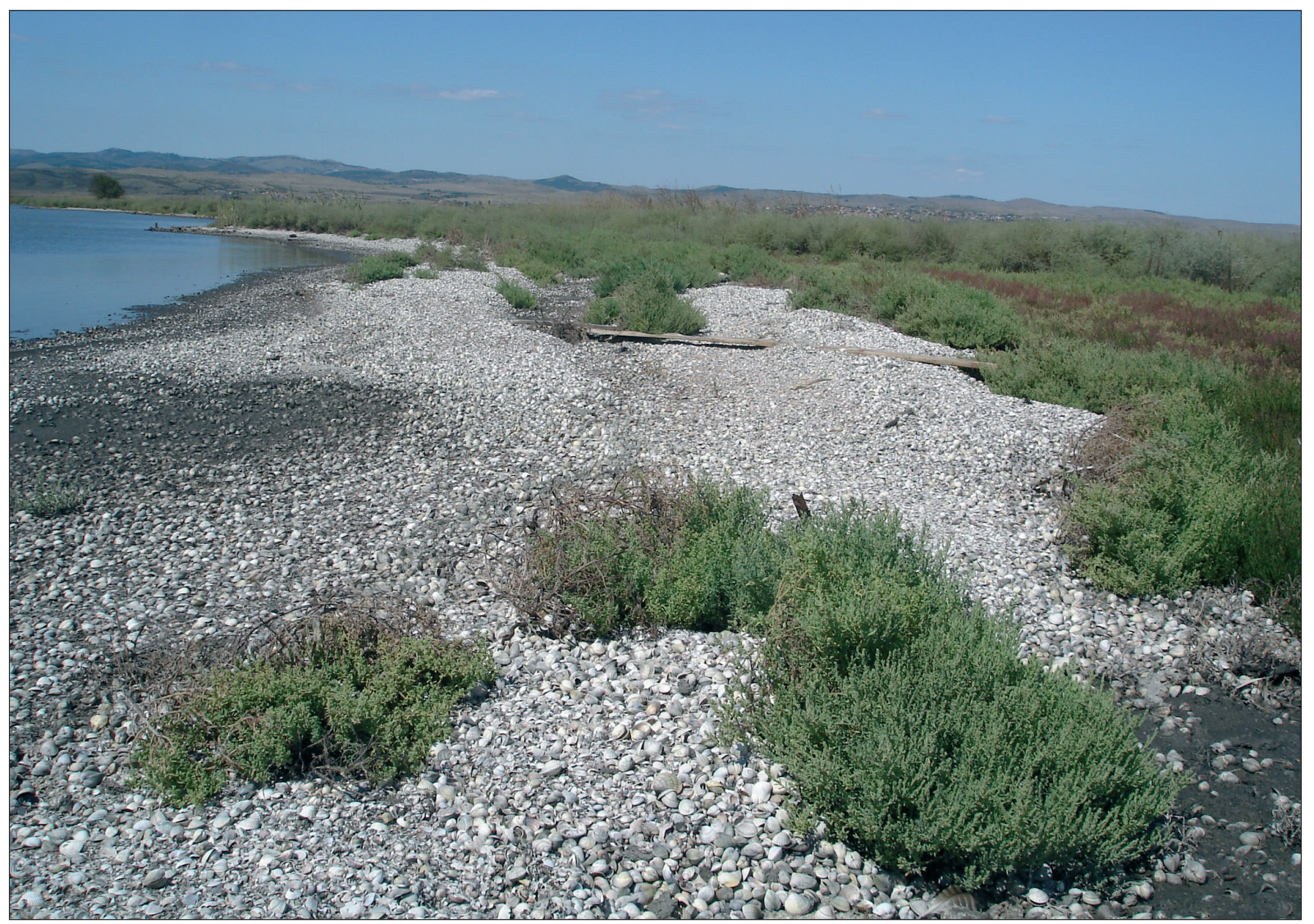

Figure 4: The association Suaedo-Bassietum hirsutae in Pomoriisko Lake (Burgas District).

Slika 4: Asociacija Suaedo-Bassietum hirsutae ob jezeru Pomoriisko (okrožje Burgas). 
in Bulgaria. The phytocoenoses (Figure 4) inhabit mostly the peripheries of the lakes, with big deposits of Bivalvia shells, with the most common species Cardium edule, rarely - Syndesmya (Abra) ovata. These deposits are very rich in nitrogen, which is important for Bassia hirsuta, a nitrophilous species. The other common species are Suaeda maritima and Salicornia europaea. Rare species are Puccinellia convoluta, Limonium gmelinii, Aster tripolium.

Kaligarič \& Škornik (2006) emphasized the disputable affinity of this association to the higher syntaxa ranks (some authors as Biondi (1998) included it in Cakiletea, not in Thero-Salicornietea), but they assigned it to Salicornion patulae of Thero-Salicornietea.

\section{Ass. Juncetum maritimi (Rübel 1930) Pignatti 1953}

The phytocoenoses (Table 2, Figure 3) of this syntaxon were described in the southern part of Atanassovsko Lake (near the road Burgas - Nessebar) and the westernmost part of Beloslav Lake (near the town of Devnya). Kochev \& Yordanov (1981) found phytocoenoses dominated by Juncus mar- itimus in the following places - Varna Lake (Kazashko village) and Dourankoulak Lake (both in Varna district); Chengene skele Bay, Mandra Lake (Kraimorie village), Karaach Marsh, near Sozopol and the mouth of the Ropotamo River (all in Burgas district). The total area was estimated to about 5 ha. Our relevés were recorded in shallow (0.1-0.2 $\mathrm{m})$ salt water on the peripheries of the hyper-saline lakes. The cover of the communities was about 90 $100 \%$. The height of the layer of Juncus maritimus was $0.9-1 \mathrm{~m}$. Plants belonging to different ecological groups participated in the floristic structure of the coenoses: halophytes, such as Salicornia europaea, Suaeda maritima and Puccinellia convoluta, and some hydrophytes like Phragmites australis.

\section{Ass. Crypsidetum aculeatae Wenzel 1934 em. Mucina 1993}

This association (Table 2) belongs to the vegetation of the dry bottoms of the water bodies of different size. The phytocoenoses of Crypsis aculeata (Figure 5) were recorded near the villages of Radetski (Stara Zagora district), Blatec (Sliven dis-

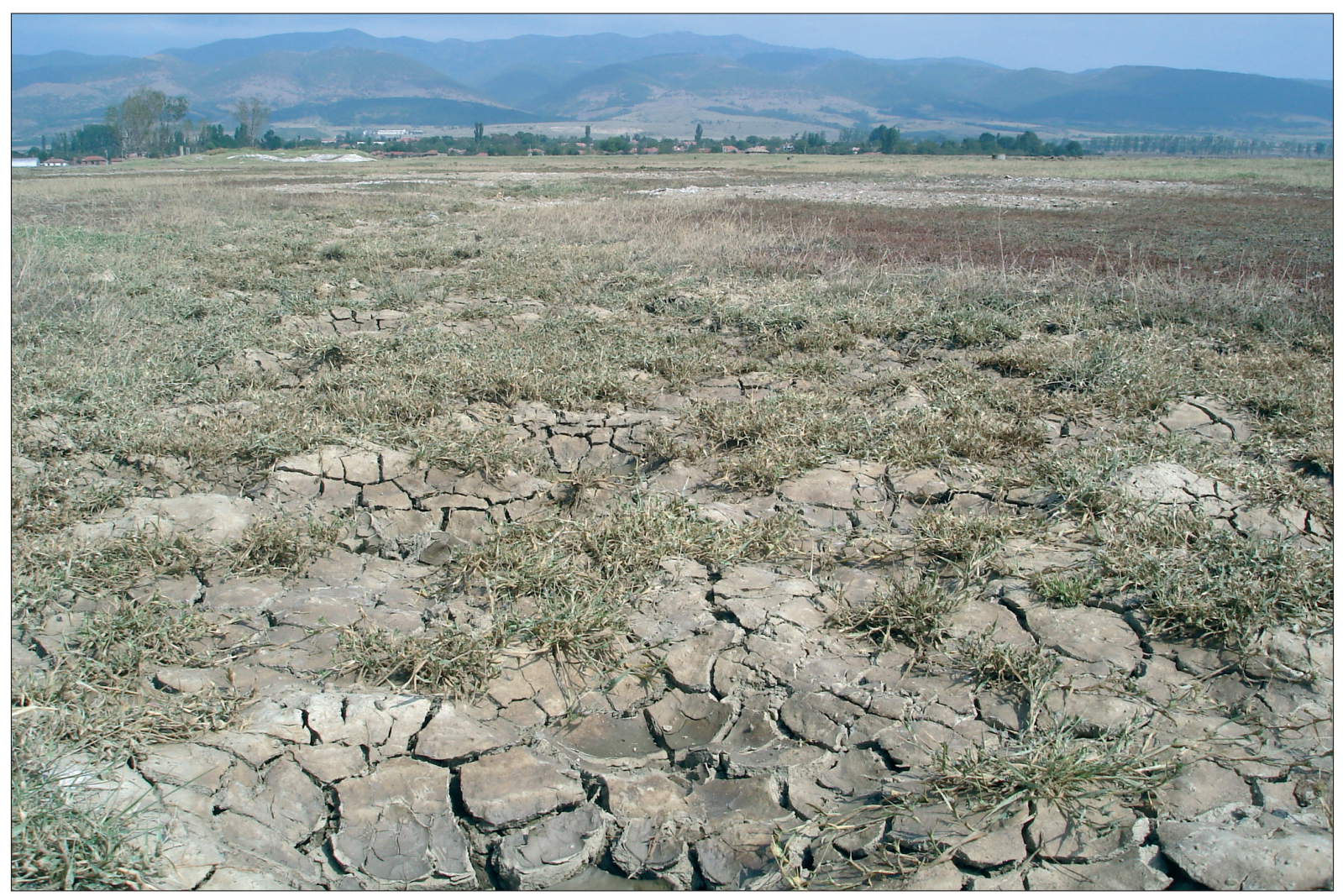

Figure 5: The association Crypsidetum aculeatae in the locality near Blatec village (Sliven District).

Slika 5: Asociacija Crypsidetum aculeatae blizu vasi Blatec (okrožje Sliven). 
trict) and Rudnik (northwards from Atanassovsko Lake - Burgas district). These phytocoenoses cover small areas on the bottom of drying temporary pools. The cover varies between 30 to $80 \%$ and species composition is relatively poor. Besides the main species, other grasses are Puccinellia convoluta, Echinochloa crus-galli and Cynodon dactylon. Other halophytes participating in the community are Suaeda maritima, Limonium vulgare, Atriplex tatarica and some others.

We can suppose that this association has wider distribution in the country. Ganchev et al. (1971) have pointed out the following places where Crypsis aculeata plays a dominant role in some phytocoenoses, such as Karaboaz Floodplain (Pleven district), the town of Aitos and Atanassovsko Lake (Burgas district), and the village of Marikostinovo (Blagoevgrad district). The species and its phytocoenoses had a wider distribution along the Danube in the past, when the river flooded the floodplains and many small pools dried after the river retraction. Such phytocoenoses were described in the marshes of Belene (Persina) island by Stoyanoff (1948).

This association has been mentioned for Bulgaria by Vicherek (1973), but without any detailed data or relevés. Micevski (1965) described a new association Crypsidetum aculeatae balcanicum from Ovče polje (today in FYROM). The presented 7 relevés contained only 9 species with wide distribution in Europe and did not prove any geographical specificities of the syntaxon. Because of the poor species composition and the clear ecological differentiation of the communities described in the present study, we accepted that the Bulgarian communities belong to the same association as in Central Europe and Romania.

\section{Ass. Heleochloetum alopecuroidis Rapaics et Ubriszy 1948}

This syntaxon (Table 2) is very similar to the previous one. The communities (Figure 6) described were near the villages of Rudnik (Burgas district) and Blatec (Sliven district). These pioneer communities occupy the drying bottoms of temporary pools, and their maximum development is soon after the receding of waters. The cover varies between 50 and $90 \%$. The phytocoenoses had poor species composition. Other species, often participating in

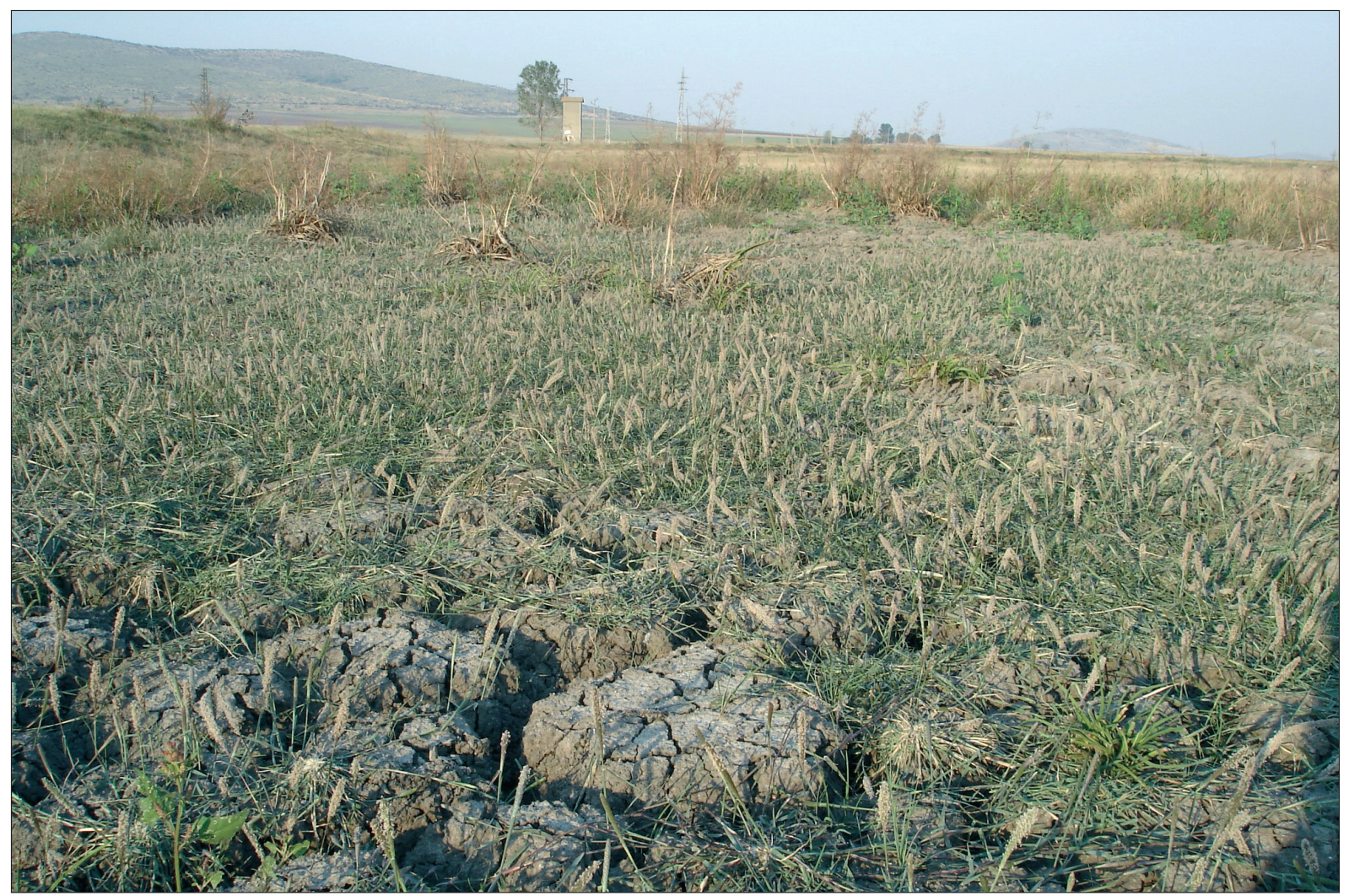

Figure 6: The association Heleochloetum alopecuroidis in the locality near Radecki village (Stara Zagora District).

Slika 6: Asociacija Heleochloetum alopecuroidis v bližini vasi Radecki village (okrožje Stara Zagora). 
the communities, were Puccinellia convoluta, Echinochloa crus-galli and Cynodon dactylon.

Ganchev et al. (1971) reported about $30 \mathrm{dka}$ occupied by communities dominated by Crypsis alopecuroides from the vicinities of the villages of Roza (Yambol district) and Mladovo (Sliven district). The dominant species is common along the Danube, but its communities there have different ecological peculiarities. They develop a belt in the middle and the upper part of the riverbank, which is flooded every year. The species composition of the communities is also different - it is not a typical halophytic one, but is rich in annual hygrophytes like Dichostylis michelianus, Cyperus fuscus, Eleocharis acicularis, Gnaphalium uliginosum and some others. Although the publication records are scanty, we have enough information to conclude that they belong to another alliance Nanocyperion flavescentis Koch 1926 - and probably to the association Dichostylido-Heleochloetum alopecuroidis (Timar 1950) Pietsch 1973.

\section{Ass. Diantho pallidiflori-Puccinellietum convolutae ass. nova hoc loco, holotypus relevé No. 4, Table 3}

This is the main syntaxon in the interior part of Southeast Bulgaria. The association (Table 3) is a very polymorphic one. The phytocoenoses (Figure 7) depend on the soil type and on the level of the underground waters. They determine the cover, species richness, and the dominant role of the species, especially the grasses such as Elymus elongatus, Puccinellia convoluta and Cynodon dactylon.

These communities occur on Solonetz soils. Most of them are of secondary origin from other saline types - Eutric Gleyosols, Gleyic Vertisols, and Fluvisols (Ninov 2002). The total cover of the phytocoenoses varied between 20 and $100 \%$, but was usually high - 80-90\%. Depending on the soil peculiarities, different species could form different sub-layers, which determine different facies of the association. The most important factor is the soil

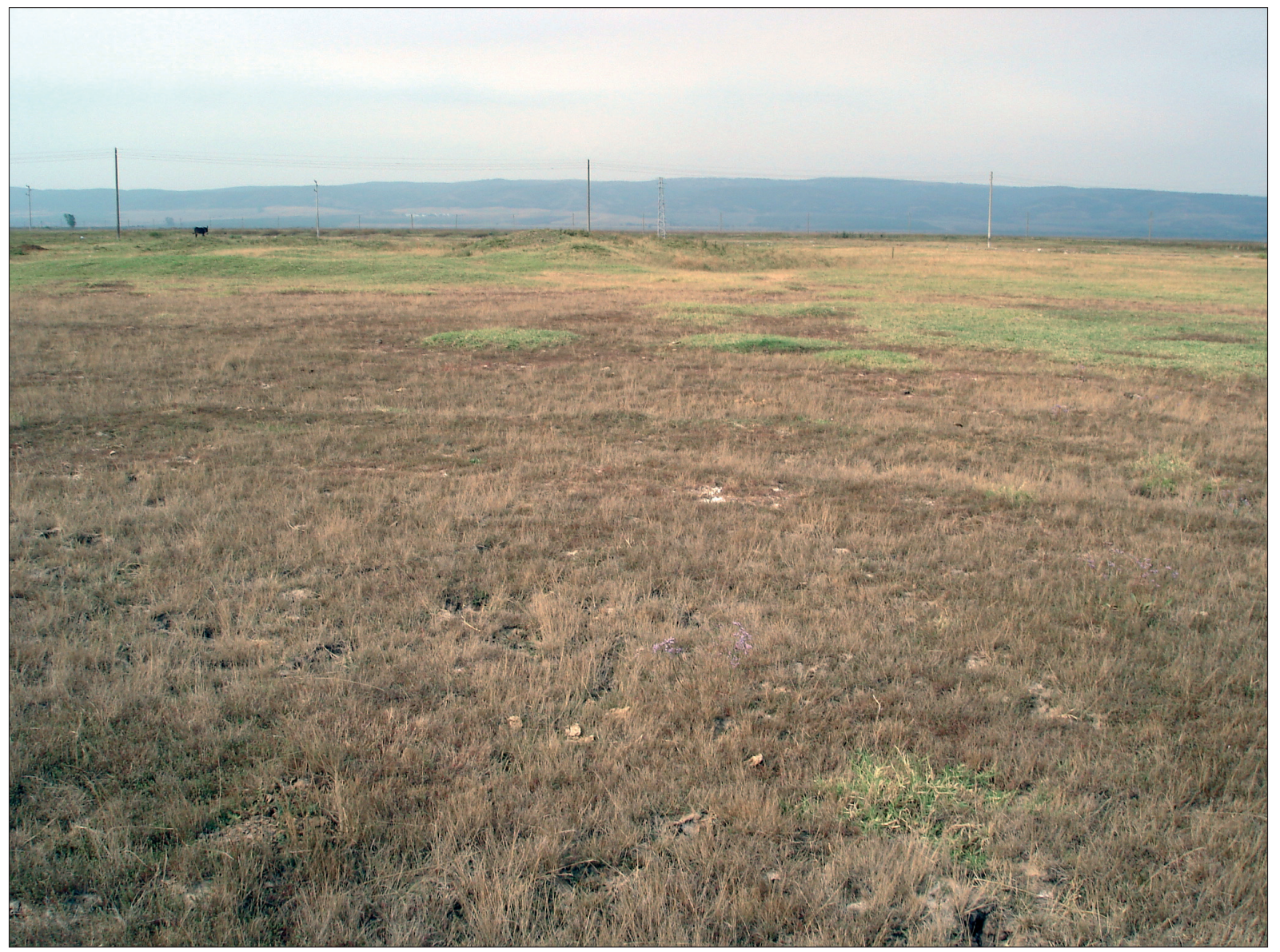

Figure 7: The association Diantho-Puccinillietum convolutae in the locality near Atolovo village (Yambol District). Slika 7: Asociacija Diantho-Puccinillietum convolutae pri vasi Atolovo (okrožje Yambol). 
moisture. The wettest soils are near the small rivers or on the places of former marshes. They had the appearance of wet meadows. Such communities were established near the town of Radnevo, the villages of Sigmen (former Sigmen Marsh) and Radetski (respectively Stara Zagora and Burgas district). They had taller layers $(1-1.20 \mathrm{~m})$ dominated by Elymus elongatus.

The most constant grass species was Cynodon dactylon, which participated in all phytocoenoses, but its cover depended on the presence/absence of a higher sub-layer. The high constancy of Cynodon dactylon in different types of halophytic communities is specific for Southeast Europe (see Micevski 1965, T,opa 1939), but because of its wide ecological flexibility it does not play a diagnostic role in the association. There were some phytoceonoses whose appearance was determined by plant species different from grasses. These were three communities from the village of Trapoklovo (Sliven district) and Atolovo (Yambol district), which was dominated by Artemisia santonicum and one phytocoenosis from Radnevo (Stara Zagora district) dominated by Juncus gerardii. One community from Radnevo was dominated by Chrysopogon gryllus and it demonstrated the advanced processes of xerophytisation. The phytocoenoses near the villages of Trapaoklovo and Atolovo had a more "steppe" (dominance of short grasses) appearance than the others.

In spite of the different appearance and dominant structure, this polymorphic group could not be divided into different sub-associations or even variants. These seemingly different groups are only different facies, whose appearance depends mainly on the soil conditions. The diagnostic species group included the following taxa: Puccinellia convoluta (IV), Elymus elongatus (III), Polygonum pulchellum (III), Limonium vulgare subsp. serotinum (II), Dianthus campestris subsp. pallidiflorus (II), Scilla autumnalis, Centaurium spicatum (II). These species characterize the geographic region of the origin and the distribution of this association. Southeast Bulgaria falls into the transitional zone between the Continental and the Mediterranean climatic types. The Mediterranean influence is demonstrated by the participation of species distributed in the Mediterranean region, like Scilla autumnalis, Polygonum pulchellum, Centaurium spicatum. These species do not play a diagnostic role in the syntaxa distributed in Central Europe southwards to Romania (see Borhidi 2003, Donit et al. 1992, Donit et al. 2005 etc.). The species Scilla autumnalis even does not occur to the North of Stara Planina Mts. The most specific group of di- agnostic species included Limonium vulgare subsp. serotinum and Dianthus campestris subsp. pallidiflorus. They are endemics mostly for Southeast Europe. $D i$ anthus campestris subsp. pallidiflorus is distributed in South Bulgaria (and probably North Greece) and the Crimean Peninsula, southeastern part of Russia and South Ukraine (Jalas \& Suominen, eds. 1988). Its localities in Bulgaria are isolated and this species is associated with the halophytic habitats. There are also other examples revealing the importance of isolated saline terrains for the processes of endemic speciation. Other endemic species on saline terrains are some Limonium species - Limonium asterotrichum in South Bulgaria or Limonium bulgaricum in North Bulgaria. The diagnostic grass species, like Elymus elongatus and Puccinellia convolute, have different diagnostic values. Elymus elongatus is more flexible and participates in different types of communities, most of them not on saline soils. The described associations with equal names Agropyretum (Elymetum) elongati in neighbouring Romania (Şerbănescu 1965) and Greece (Babalonas \& Papastergiadou 1990) are different. The Romanian syntaxon belongs to the salt steppe vegetation (without any Mediterranean species), but the Greek communities have some hygrophytic and mesophytic species, such as Oenathe silaifolia, Carex divisa, Daucus guttatus and Holoschoenus vulgaris. Other associations, where Elymus elongatus is a constant and diagnostic species, were described along the whole Mediterranean coast, but they are more typical for the coastal salt marshes with a sandy bottom. For example, the associations Hainardio-Elymetum elongati (Croatia) and Agropyro elongati-Inuletum crithmoidis (Spain) are included in Juncetea maritimi (see Horvatić 1934, Alcaraz et al. 1986). There are data for both ecological types of the communities dominated by Elymus elongatus and in Bulgaria. Ganchev et al. (1971) described different localities with occurrence of these communities. Species compositions of the communities near Sozopol, Ropotamo River, Balchik, Ravadinovo, Cape Atiya, were more similar to the coastal (maritime) type, while those near the villages of Atolovo, Gorno Aleksandrovo and the town of Radnevo belonged to the type probably presented in the association Diantho pallidiflori-Puccinellietum convolutae.

One of the most constant grass species in this group of relevés - Puccinellia convoluta - played also a very specific diagnostic role in the communities. The species did not have diagnostic importance for the halophytic syntaxa, described in other Southeast and Central European countries: Romania (Ivan et al. 1993, Donită et al. 2005), Hungary (Borhidi 
2003), Austria (Mucina 1993) in contrast to Puccinellia limosa and $P$. distans. The species increases its phytosociologal importance in the halophytic vegetation in South Europe. The association Puccinillietum convolutae described in FYROM by Micevski (1965) had very poor species composition and the relevés were not similar to the Bulgarian ones. Micevski (1965) emphasized the increasing phytocoenological importance of this species (common along the Mediterranean coast) in the southern part of Europe. There are several syntaxa with high constancy of Puccinellia convoluta, described by different authors (Braun-Blanquet 1952, Géhu 1976, Géhu et al. 1984, 1992) in the coastal regions of France and Italy. However, they belong to the Mediterranean class of semi-scrubby halophytic communities of Salicornietea fruticosae, that do not occur in Bulgaria.

The high phytocoenological importance of Puccinellia convoluta has been emphasized by Ganchev et al. (1971). Different communities dominated by this species or with co-dominants, such as Puccinellia distans, Hordeum hystrix, Crypsis aculeata, Suaeda maritima, Camphorosma monspeliaca, C. anna, Limonium bulgaricum, cover hundred hectares on the salt places in Veliko Turnovo, Sliven, Yambol, Burgas and Plovdiv districts. They are widespread in the interior part of the country as well as in the coastal zone. Their patterns of distribution are opposite to the communities of Puccinellia distans, covering smaller areas mostly in the coastal territories.

Other species, which have the constancy of two or more than two in the Bulgarian groups of phytocoenoses, are not so typical. They are wide-spread halophytes like Camphorosma monspeliaca (II), Hordeum hystrix (II), Spergularia marina (II), Lotus tenuis (II), Bupleurum tenuissimum (II), Atriplex tatarica (II), Lactuca saligna (II); or ruderals or semi-ruderals as Cichorium intybus (II), Plantago lanceolata (III), Achillea millefolium (II) and Eryngium campestre (II). The specificity of this new Bulgarian association is determined by its particular species composition, ecological peculiarities and physiognomy.

\section{Ass. Aeluropetum littoralis (Prodan 1939) Şerbănescu 1965}

The species Aeluropus littoralis was evaluated as "vulnerable" in Bulgaria by the project "Red Lists of Plants in Bulgaria". It has scattered localities only along the Black Sea coast. The presented relevés (Table 2) were recorded in different parts of Atanassovsko Lake. There are some data (Ganchev et al. 1971) about the communities dominated by Aeluropus littoralis near Pomorie and Atiya Bay (Burgas district) and Durankulak Lake (Dobrich district).

The described communities were distributed in the hyper-saline lakes on the higher and drier zones in the periphery of the salt basins. The soil type was Solonchaks. These communities are very close to the neighboring phytocoenoses of TheroSalicornion (mostly Salicornietum prostratae), but occupy the places whose drying takes more time. The communities were with high coverage (near 100 $\%)$ and poor floristic composition. Other species participating in their composition were mostly of alliance Thero-Salicornion - Suaeda maritima, Salicornia europaea, but included also Puccinellia convoluta, Aster tripolium and some others. Ganchev et al. (1971) mentioned the possibility of using these communities as pasturelands, but their economical importance is low, because of the limited areas occupied by them.

Aeluropus littoralis is widespread mostly in the coastal territories of the Mediterranean and the Black Sea Coasts. There are several associations described in different countries, where the species has a great diagnostic role. Most of them have richer species diversity than the Bulgarian one. The most numerous are the associations from the Danube Delta and Azov Sea: Aeluropo-Salicornietum Krausch 1965; Aeluropo-Puccinellietum limosae Popescu et Sanda 1975, Limonio-Aeluropetum littoralis Sanda et Popescu 1992, Tripolio vulgaris-Aeluropetum littoralis Dubyna et Neuhäuslová 2000.

The closest to the Bulgarian group of phytocoenoses is the Romanian association (from the Danube Delta) - Aeluropetum littoralis (Prodan 1939) Şerbănescu 1965. The differences between the two groups (the presence of Puccinellia convoluta in the Bulgarian phytocoenoses) are not sufficient for distinguishing a new association. The association Aeluropetum littoralis (Prodan 1939) Şerbănescu 1965 was revised by Pop (2002) and it was given the status of a new subassociation aeluropetosum in the association Halimiono pedunculatae-Aeluropetum littoralis Géhu et al. 1994. However, Pop (2002) did not determine the subassociation typicum (but only aeluropetosum and halimionietosum - the second one probably is the typicum), which makes his subassociation invalid because it contradicts Art.5 of the Code. Additionally, Pop (2002) used Aeluropus littoralis, which is a diagnostic species for the association, as a differential species for the subassociation. Also, Géhu et al. (1994) did not analize 
the Romanian syntaxa published to that date (described in the same region - Danube Delta) with a high diagnostic role of Aeluropus littoralis, and from the analysis of Pop (2002) we understand that they are identical. The assocation Aeluropetum littoralis described by Babalonas (1979) from Greece has the same name as the one described by Şerbănescu (1965). In this case, the revision of Babalonas et al. (1995), which treated the association LimonioAeluropetum littoralis (Bab. 1979) Géhu et al. 1979 as a synonym of the association Aeluropetum littoralis Babalonas 1979, is not correct. The Bulgarian phytocoenoses are more similiar to the Romanian group of phytocoenoses than to the Greek ones, the latter being the more Mediterranean ones.

An other disputable issue is the affiliation of the communities dominated by Aeluropus littoralis along the Black Sea coast to syntaxa of ranks higher than the association level. The described associations in Spain (Aeluropo littoralis-Puccinellietum fasciculatae (Rivas Goday 1955) Rivas Mart. et Costa 1976. emend. Rivas Mart. 1984; Aeluropo-Juncetum subulati Cirujano 1981) or Italy (Puccinellio festuciformis-Aeluropetum littoralis (Corb. 68) Géhu et Costa in Géhu et al. 1984, Aeluropo-Limonietum cercinensis Barbagallo, Brullo et Furnari 1991, AeluropoSarcocornietum alpini Brullo in Brullo, Santis et Furnari 1991) belong to the class Juncetea maritimi. Géhu et al. (1994) included in this class also the association Halimiono-Aeluropetum littoralis from the Black Sea coast of Romania. Dubyna et Neuhäuslová (2000) accepted the concept of the association Tripolio vulgaris-Aeluropetum belonging to the order Artemisio santonici-Limonietalia gmelinii Golub \& V. Solomakha 1988, alliance Salicornio-Puccinellion Mirkin in Golub \& Solomakha 1987. In fact, there is not a big difference in the species compositon of the communities of Aeluropus littoralis described in Bulgaria (present study), Romania (Şerbănescu 1965, Géhu et al. 1994, Pop 2002) and Ukraine (Dubyna \& Neuhäuslová 2000). Probably future revisions will clarify the syntaxomical relations of these communities on the western coast of the Black Sea.

\section{Ass. Bupleuro tenuissimae-Camphorosmetum monspeliacae ass. nova hoc loco, holotypus relevé No. 41, Table 4}

The communities with significant participation of Camphorosma monspeliaca have wide distribution in Bulgaria, but the ecological peculiarities of the species in North and South Bulgaria differ. The north- ern populations of Camphorosma monspeliaca participate in the floristic composition of the petrophytic steppes. Tzonev (2002) described a new association Hedysaro bulgaricum-Camphorosmetum monspeliacae from a small region of the Middle Danubian plain (the municipalities of Levski and Svishtov). These phytocoenoses occupy steep slopes (mostly with southern exposition) on the basis of opened Cretaceous clay marls, which are rich in different iron oxides with reddish colour. These oxides are salty and this fact determines the participation of some halophytes like Camphorosma monspeliaca and Artemisia santonicum, which have the dominant role. However, the species composition is richer due to the typical Pontic steppe species, often with endemic subspecies, such as Hedysarum grandiflorum subsp. bulgaricum, Genista sessilifolia subsp. trifoliata, Thesium simplex subsp. moesiacum, Centaurea thracica, Ephedra distachya, Tanacetum millefolium, Agropyron cristatum, Aster oleifolius, and Astragalus corniculatus. Tzonev et al. (2006) described another syntaxon with Camphorosma monspeliaca, namely the subassociation camphorosmetosum monspeliacae of the association Alysso caliacrae-Artemisietum lerchianae Tzonev et al. (2006) from the locality of "Chirakman", near the town of Kavarna (Black Sea coast). The second group of communites occupies similar places as in the Middle Danubian plain - steep slopes above the sea, on Sarmatian marls with some oxides. They are rather rich in steppe species like Agropyron cristatum, Aster oleifolius, Astragalus vesicarius, Cephalaria uralensis, but the halophytes are limited only to the two dominants - Artemisia lerchiana and Camphorosma monspeliaca.

In South Bulgaria, Camphorosma monspeliaca is a typical halophytic species in the valleys of the small rivers on typical Solonetz soils. These valleys are flooded in spring and early summer, but dry out afterwards. The described phytocoenoses (Figure 8) were near the villages of Blatec, Zhelyu Voivoda and Trapoklovo (Sliven disitrict), Bikovo and Atolovo (Yambol district), Sigmen and Rudnik (Burgas district). Ganchev et al. (1971) described communities of Camphorosma monspeliaca also in other places: the villages of Radinovo and Kostievo (Plovdiv district), Dragodanovo, Novoselec, Kovachevo, Omarchevo, Konyovo and Mladovo (Sliven district), Opalchenec (Stara Zagora district) and near the towns of Aitos, Nova Zagora and Straldzha.

The level of salinization of the ground was high and there were white salt concretions of different size - often $4-5 \mathrm{~cm}$. The phytocoenoses of this asso- 


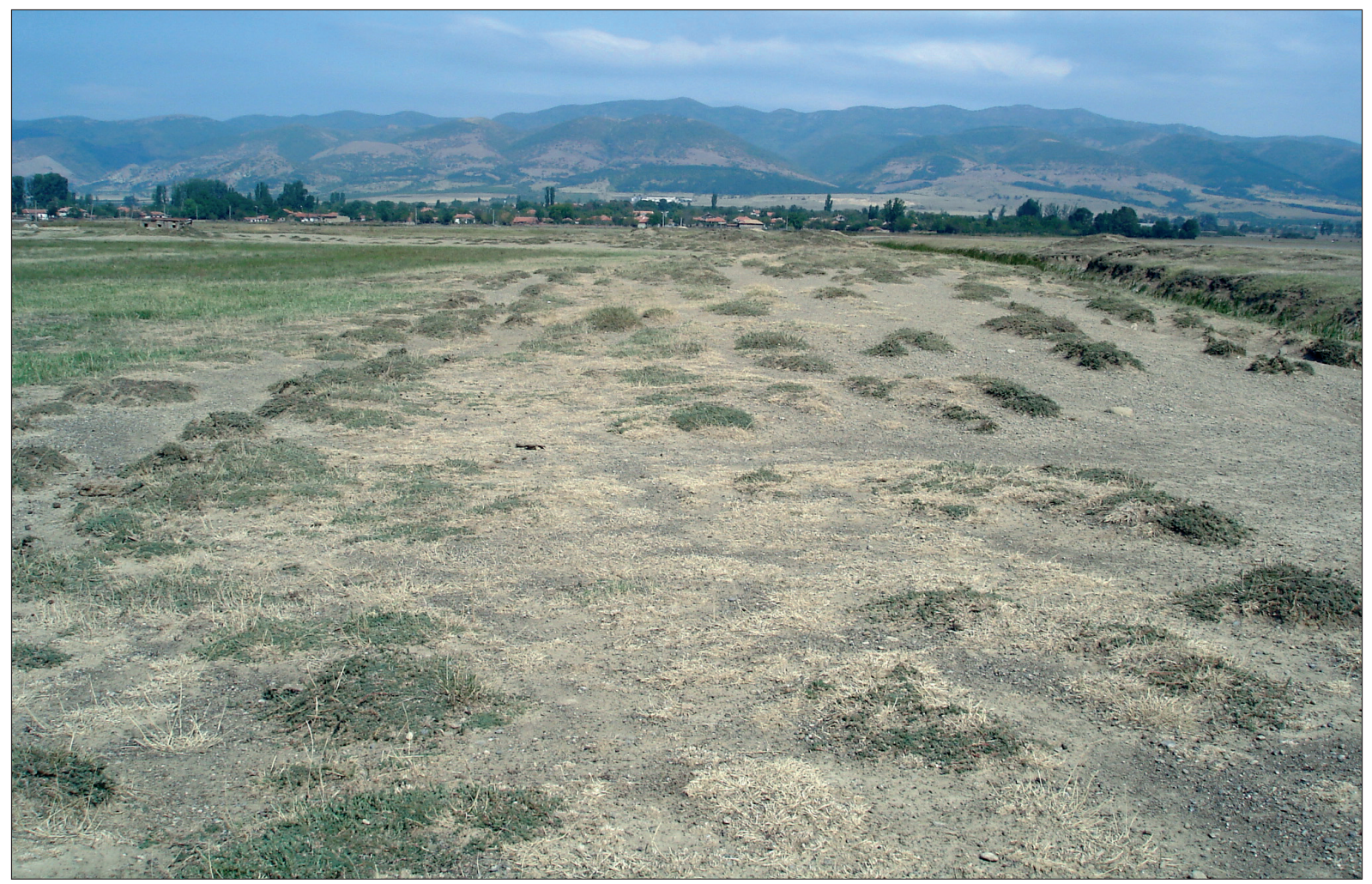

Figure 8: The association Bupleuro-Camphorosmetum monspeliacae in the locality near Zhelyu vojvoda village (Sliven District). Slika 8: Asociacija Bupleuro-Camphorosmetum monspeliacae pri vasi Zhelyu vojvoda (okrožje Sliven).

ciation were open and their cover was mostly about 60-70 \%. The main species - Camphorosma monspeliaca formed small micro-eminences rising several centimetres above the neighboring flat ground. The size of these micro-eminences was about $0.5-1$ $\mathrm{m}^{2}$. The other more frequent species are Cynodon dactylon (IV), Puccinellia convoluta (IV), Bupleurum tenuissimum (III), Plantago lanceolata (II) and Polygonum pulchellum (II).

This association (Table 4) was very close to $D i$ antho pallidiflorii-Puccinellietum convolutae. This fact was proven by the high constancy of Puccinellia convoluta and Cynodon dactylon, as well as by the participation of a high number of diagnostic species from the above mentioned association - Polygonum pulchellum (II), Dianthus campestrissubsp. pallidiflorus (I), Scilla autumnalis (I), Limonium vulgare subsp. serotinum (I) and Elymus elongatus (I). A particular feature is the higher constancy of Bupleurum tenuissimum (III). This taxon is widespread in saline communities all over Europe, but is of no diagnostic importance. For example, this species participates with low constancy (I) in some halophytic associations in Romania (Ivan et al. 1993). Borhidi (2003) mentioned the species only in the association Limo- nio gmelinii-Artemisietum santonici and it is presented in the association Camophorosmetum monspeliacae of Micevski (1965) with constancy I. The higher presence of Bupleurum tenuissimum in the Bulgarian phytocoenoses demonstrates their more continental origin and climatic influence in comparison to the Macedonian ones. The species participates in the composition of association Diantho pallidifloriPuccinellietum convolutae with constancy II (22\%), lower than in Bupleuro tenuissimae-Camphorosmetum monspeliacae (III - $41 \%$ ). This higher presence is determined by some ecological differences. The second syntaxon has lower cover and lower participation of grasses (Poacaeae), which allows for the higher presence of species different from grasses, like Bupleurum tenuissimum.

We can conclude that the two syntaxa are very similar and their differences depend on the degree of drying and the level of the underground waters in the driest summer period. The association Diantho pallidiflori-Puccinellietum convolutae covers areas that are less saline and the soil moisture is appropriate for development of more "meadowlike" communities. The phytocoenoses of BupleuroCamphorosmetum monspeliacae are more open, the 
terrains are subjected to a stronger summer drying and the concentration of salts in the soils reaches its highest values compared to all other communities. They have a more expressed "semi-desert" appearance and their geographical isolation is demonstrated by the participation of some endemic species and subspecies. There are also transitional types between these two associations.

The communities with a high diagnostic role of Camphorosma monspeliaca are distributed in South Europe - mostly in the Mediterranean region. Most similar to the Bulgarian syntaxa are the associations Camphorosmetum monspeliacae balcanicum Micevski 1965 (FYROM) and Camphorosmetum monspeliacae (Țopa 1939) Şerbănescu 1965 (Romania). Both associations have floristic differences that derive from their geographical distribution. The Romanian association is poor in Mediterranean and endemic taxa, while the Macedonian association compared to the Bulgarian one is richer in such taxa. Similarities between these associations are the high presence of Cynodon dactylon, Puccinellia convoluta and Bupleurum tenuissimum, but with constancy I. There are many species that do not occur in the Bulgarian group of relevés, like Plantago coronopus (V), Matricaria chamomila subsp. salina (V), Bromus japonicus (IV), Trigonella monspeliaca (IV) and Stratonostoc commune (IV). Micevski (1965) named the association in Macedonia (FYROM) only as Camphorosmetum monspeliacae, in spite of the two diagnostic species identified - Camphorosma monspeliaca and Plantago coronopus. He noted that his association is a synonym of Camphorsometum pilosae Țopa 1939 subass. Nostocetosum commune Bacar 1957, despite the differences exhibited at the association level. According to the ICPN (Weber et al. 2000), this association is now invalid. Micevski (1965) did not observe the rule of priority, because the association was already named by Țopa (1939), even though as Camphorosmetum pilosae (Camphorosma monspeliaca v. pilosa). The association of Țopa (1939) was validated in the same year by Şerbănescu(1965). The Romanian phytocoenoses described in the northern periphery of the range of Camphorosma monspeliaca showed a more typical Central European composition (see Țopa 1939) than the Bulgarian association. The ecological plasticity of Camphorosma monspeliaca is demonstrated by the described associations in different vegetation types in the Mediterranean region. For example, Camphorosma monspeliaca is a diagnostic and constant (including dominant) species in the coastal marshes (Juncetea maritimi, Puccinellion caespitosae) in Spain (Ladero et al. 1984), coastal garriges (Rosmarinetea officinalis) in France (Molinier 1934), and in different vegetation types in Italy (Biondi et al. 1990, 2001) etc. These communities are substantially different from the Bulgarian syntaxa.

\section{Ass. Camphorosmetum annuae Rapaics ex Soó 1933}

The association is presented from 5 relevés only from the vicinities of Blatec village (Sliven district). Is spite of the wider distribution of the species, which was indicated by Yordanov \& Kuzmanov (1966) and which includes the regions of Burgas, Nessebur, Ajtos, Karnobat, Sliven, Plovdiv, Nova Zagora, Yambol; the phytocoenoses with a dominant role of Camphorosma annua, were established by Ganchev et al. (1971) only from the villages of Mladovo and Atolovo (Yambol district).

The phytocoenoses of the association occupy the furrows of the terrain, which are flooded until the beginning of the summer. The soils are typical Solonchaks and the salt concentration is high. These communities are a pioneer succesional stage of the communities of Camphorosma monspeliaca and both form a complex, but Camphorosma monspeliaca occupies the small elevations of the terrain. The communities of Camphorosma annua have open cover (50-70\%) and very poor floristic composition. Only Puccinellia convoluta and Cynodon dactylon participate in these communities.

The poor floristic composition (only 2 species) characterizes the association Camphorosmetum annuae balcanicum, which has been descibed by Micevski (1965) from the territory of former Yugoslavia. The high presence of Puccinellia convoluta can not be the reason for the describtion of a new association. In spite of some differences, the Bulgarian phytocoenoses must be assigned to the existing association Camphorosmetum annuae, as was done for the communities of Camphorosma annua in Romania by the Romanian authors (T,opa 1939, Sanda et al. 1999, Pop 2002 etc.).

\section{Ass. Petrosimono brachiatae-Puccinillietum convolutae ass. nova hoc loco, holotypus relevé No. 2, Table 2}

The described communities (Figure 9) of the association (Table 2) are situated in the Pomoriisko Lake. The phytocoenoses were in the second suc- 


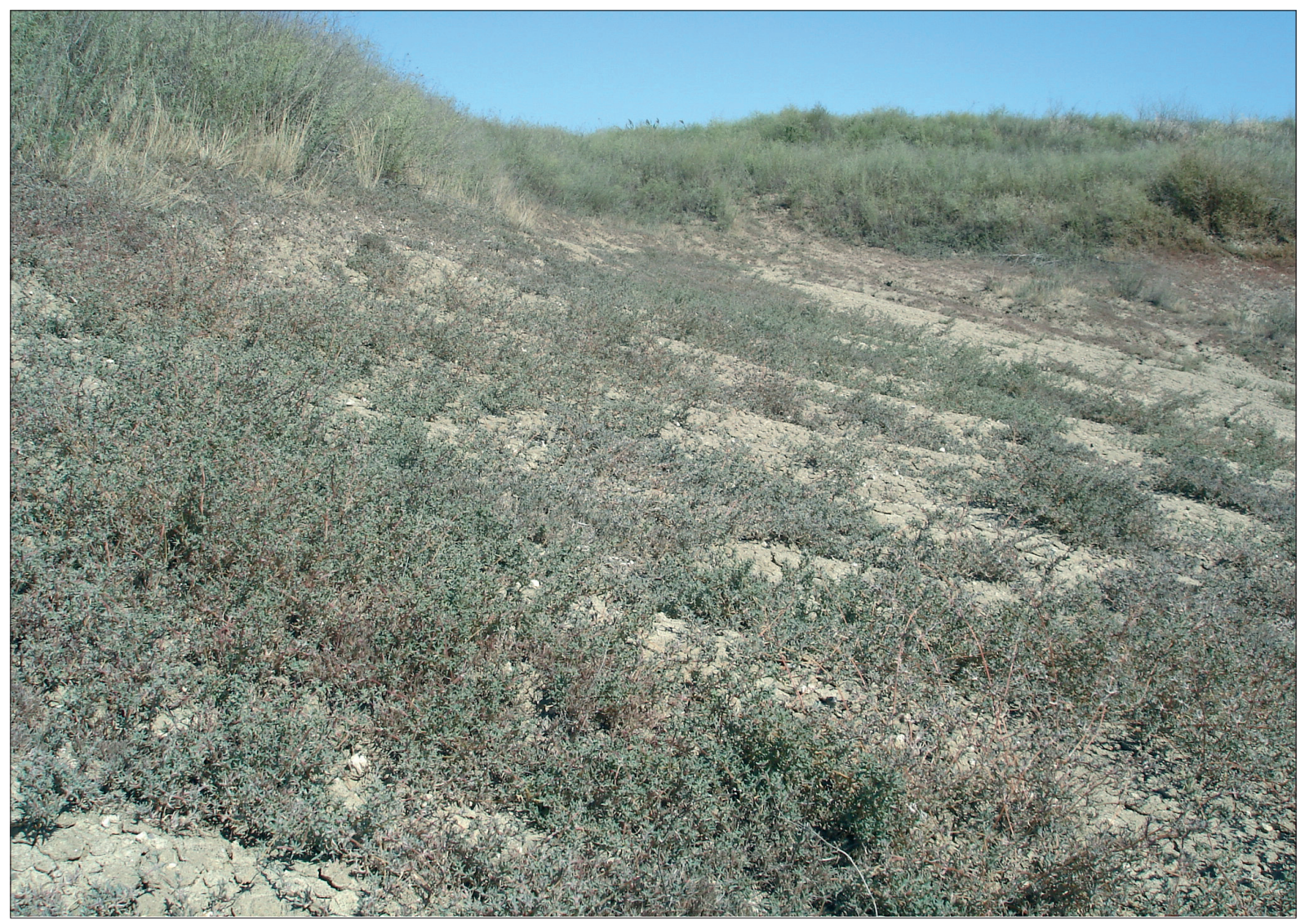

Figure 9: The association Petrosimonio brachiatae-Puccinillietum convolutae in Pomoriisko Lake (Burgas District). Slika 9: Asociacija Petrosimonio brachiatae-Puccinillietum convolutae ob jezeru Pomoriisko (okrožje Burgas).

cession stage of the drying of hyper-saline basins. The association Salicornietum prostratae develop on the wetter places. They surround the concentric belts of the communities of Petrosimonia brachiata and Puccinellia convoluta. These communities are more open (50-60\% cover) than the neighboring ones of Salicornietum prostratae and occupy very hard, dry salty mud. The coenoses are poor in species, with the obvious dominant role of the diagnostic species - Petrosimonia brachiata and Puccinellia convoluta.

Petrosimonia brachiata has very limited distribution in Bulgaria (Southern Black Sea coast, only in Atanassovsko and Pomoriisko Lakes) and here is the northwesternmost part of the species range. It was evaluated as critically endangered in the "Red List of Bulgarian Plants". The main part of its range is in the saline steppes and deserts in Southern Russia to Kazakhstan, Anatolian Plateau to Iran, where different associations with its participation have been described (Zohary 1973, Golub \& Mirkin 1986, Korotkov et al. 1991, Vural et al.
1999). Most of these syntaxa belong to different classes and include semi-desert species that do not occur on the Balkan Peninsula. The specificity of the phytocoenoses of Petrosimonia brachiata in Bulgaria distinguishes the new association.

\section{Artemisia santonicum comm.}

These communities (Table 5) are of secondary origin, because they have been described on the dikes of the salt-pans of Pomorie (Pomoriisko Lake) and Burgas (Atanassovsko Lake). The dikes are 1.5$2 \mathrm{~m}$ high and were constructed by relatively large stones at the beginning of the $20^{\text {th }}$ century. The phytocoenoses have a high cover $-70-100 \%$. The first sub-layer - 1-1.3 m high - is formed by Artemisia santonicum, which is an obvious dominant. The other species with constancy higher than I are Puccinellia convoluta (III), Elymus elongatus (II), Melilotus officinalis (II), Atriplex tatarica (II), Bromus arvensis (II). This species composition demonstrates a 
secondary origin of these communities, determining their semi-ruderal appearance. Evidently, the dominant species covered these artificial constructions because they provide appropriate ecological conditions. The dikes have been used as pastures for cattle and domestic pigs for a long time. The pasture activities resulted in dunging the dikes and the regulation of vegetation development there. The animals (especially pigs) graze actively on the wormwood, thus regulating its population. The main reason for the preference of the wormwood by the animals is the anthihelmintic drug "santonin". Massive grazing by wild animals (deer, wild boar) of the wormwood in its natural locality can be observed near the mouth of Ropotamo river. After the establishment of the Atanassovsko Lake reserve and Pomoriisko Lake protected area the grazing of domestic animals stopped. This is the reason for the secondary increase of the wormwood populations on the dikes and the formation of monodominant communities with a high cover.

These semi-ruderal communities are not similar to other steppe communities of Artemisia santonicum that are widespread in the steppes and semi-deserts of Central, Southeast Europe, Russia, Ukraine, Kazakhstan and Asia Minor. The latter communities have a high species diversity and belong to different syntaxa of the halophytic vegetation (Korotkov et al. 1991, Ivan et al. 1993, Borhidi 2003, Donit et al. 2005). An indirect evidence of the origin of the Bulgarian phytocoenoses is the lack of any communities with dominant species Artemisia santonicum described in Ganchev et al. (1971). It indicates the period of secondary origin of the communities after the 1980s. These semi-ruderal communities are not similar to the described natural syntaxa with diagnostic species Artemisia santonicum, including the association Artemisietum santonici Soó 1947, and their syntaxonomical rank and position could be clarified after further investigations.

\section{CONCLUSIONS}

The halophytic vegetation has a limited distribution on the territory of Bulgaria. All together 11 associations and 1 community, belonging to 4 classes, 4 orders and 4 alliances were described as a result of the present study. Most of them are recorded for the first time in Bulgaria. However, they do not cover the whole diversity of the halophytic vegetation in the country, and further studies can provide more detailed information. For example, Vicherek (1973) proposed for Bulgaria the association Heleochloetum schoenoidis T,opa 1939. In 2000, the communities of Heleochloa schoenoides were found on the bottom of drying small marshes in Karaboaz Floodplain of Danube River, Pleven district (Tzonev, unpubl.), and probably they belong to the same association.

The affiliation of the Bulgarian communities, especially of Festuco-Puccinellietea, to syntaxa higher than association appears to be the most complicated question. The current species composition of the halophytic vegetation is a result of the transitional position of Bulgaria between the continental and Mediterranean climate types. The Bulgarian phytocoenoses are similar and at the same time different, when compared with the typical Mediterranean (in Greece, Italy, Spain), and the typical Continental (in Romania, Hungary, Austria, Ukraine, Russia) syntaxa. These peculiarities of the halophytic vegetation of the Central part of the Balkan Penisula were outlined by Micevski (1965), who proposed to include the communities in a new alliance Puccinellion convolutae Micevski 1965. This new alliance was accepted by Babalonas \& Papastergiadou (1990) for North Greece, too. The investigation of the Bulgarian halophytic communities of Festuco-Puccinellietea did not confirm their affiliation to the alliance Puccinellion convolutae. In spite of some evident differences, they should be classified to Puccinellion limosae, and the differences will be enough to designate probably a new sub-alliance in Puccinellion limosae rather than a new alliance. The preliminary studies on the grasslands in Bulgaria by Meshinev et al. (2005) placed the described halophytic communities in Puccinellion limosae as well. Most of the diagnostic species proposed by Micevski (1965) for Puccinellion convolutae, have a wide range of distribution, and some of them, like Camphorosma annua, C. monspeliaca, Limonium gmelinii, Scorzonera laciniata (syn. Podospermum canum), Nostoc commune participate in halophytic communities not only in Mediterranean parts of Europe, but also in Central Europe. This alliance was not accepted by Rodwell et al. (2002) in their overview of the vegetation of Europe at the alliance level. The revision of Golub et al. (2005) rejected the alliance Puccinellion convolutae, because of the unjustified unification of communities with different ecological origin and peculiarities. Additionally, most of the associations (excluding Camphorosmetum monspeliacae and Hordeo-Trifolietum parviflorum) described by Micevski (1965) are based on 
an insufficient number of relevés and species, and moreover, they are named by using a geographical epithet. In this sense, they are not valid according to the rules of ICPN (Weber et al. 2000) and need further validation.

Also, Golub et al. (2005) only on the basis of the works of Micevski (1965) from FYROM and Korzhenevsky \& Klyukin (1991) from Crimea, mechanically unified the halophytic communities on the Balkan Peninsula and Crimea in a new order Puccinellio festuciformis-Camphorosmetalia monspeliacae Golub et Karpov in Golub et al. (2005). The diagnosis of this order is characterized insufficiently on the basis of the geographic distribution only. The diagnostic species, like Camphorosma monspeliaca and Scorzonera laciniata are widespread and can not characterize the syntaxa localized on the Crimean and the Balkan Peninsulas. The alliance Plantagini coronopodoCamphorosmion monspeliacae Golub et Karpov 2005 in Golub et al. (2005) is treated as a synonym of Puccinellion convolutae Micevski 1965. However, it should be noted that the diagnostic species selected by Golub et al. (2005) are very disputable. For example, Bromus japonicus was not established in the communities of Bulgaria, and Petrosimonia brachiata is distributed on the Balkans only along the Southern Bulgarian Black Sea coast and in some places in Northern Greece. Lepidium ruderale, Crepis setosa and Veronica arvensis are ruderal species, and Crepis tectorum, Cynodon dactylon and Trifolium resupinatum are not halophytes. Therefore, the alliance does not have ecological specificity, because only the combination of diagnostic species and the geographical criteria was used for its delineation. The differences between the Bulgarian and Crimean (see Korzhenevsky \& Klyukin 1991) halophytic syntaxa are larger than their similarities.

Problematic are also the described syntaxa of Aeluropus littoralis on the Balkan Peninsula (see Pop 2002, Babalonas et al. 1995 etc.). Only further, more complete phytocoenological investigations could reveal their syntaxomic relationships and their affiliation to syntaxa higher than association.

The lack of information (small number of relevés and small investigated territories) about the halophytic vegetation on the Balkan Peninsula at the moment does not provide evidence to draw some general conclusions about the affiliation of the halophytic communities to the syntaxa with ranks higher than association. Therefore, we accepted the existing syntaxa of higher rank and searched for some differences only at association level.
The halophytic vegetation of Bulgaria has been subjected to significant human impact. The main threats are the changes in the regime of water bodies (rivers, wetlands) that affected the neighboring halophytic communities. The construction of new hotels and the tourist invasion on the Black Sea coast are other serious threats. The "Thrace" highway was projected to pass through such communities in the region of the town of Kermen. There are some negative changes observed in the halophytic vegetation, which were detected after the comparison with the previous work of Ganchev et al. (1971). For example, some dominants in the halophytic communities, described in Ganchev et al. (1971), like Camphorosma annua were found to be very limited in these communities in 2006 . Some very rare phytocoenoses, like those of Cressa cretica are probably extinct. Many places with halophytic vegetation known from the past were not confirmed during our investigation.

Despite the human degradation, the fragments of halophytic vegetation that have survived are of special importance because of the participation of many rare and threatened species (listed in the Red Data Book of Bulgaria (Velchev 1984) and in the Red Lists of Plants in Bulgaria), including some Balkan endemics. Such species are Aegilops lorentii, Dianthus campestris subsp. pallidiflorus, Halimione pedunculata, H. portulacoides, Petrosimonia brachiata, Frankenia pulverulenta, Limonium bulgaricum, L. latifolium, L. asterotrichum, L. gmelinii, L. vulgare subsp. serotinum, Cressa cretica, Plantago tenuiflora, Plantago cornutii, Taraxacum bessarabicum. This fact increases their value for the conservation of the biodiversity in Bulgaria and Europe. All halophytic syntaxa in Bulgaria are represented in the Directive 92/43/ EEC by the following habitats: 1310 Salicornia and other annuals colonising mud and sand; 1340 Inland salt meadows (priority) and 1530 Pannonic salt steppes and salt marshes (priority).

The results of our work could be used for the classification of the natural habitats and for the purposes of the European ecological network NATURA 2000 in Bulgaria, and for the conservation of the unique diversity of Bulgarian halophytic vegetation.

\section{ACKNOWLEDGEMENTS}

The authors thank Prof. Dr. Reinhard Boecker from the University of Hohenheim, Stuttgart, Germany, Dr. Marius Dimitrov from the University of 
Forestry, Sofia for the useful comments and critical remarks, and Dr. Desislava Dimitrova for the help in the language revision of the text. The study was financially supported by the Project "Red Data Book of Bulgaria", V.III, Habitats.

\section{REFERENCES}

Alcaraz, F., Garre, M., Martinez-Parras, J.M. \& Peinado, M. 1986: Notas fitosociológicas sobre el Sureste de la Península Ibérica, I. Collect. Bot. (Barcelona) 16(2): 418-423.

Babalonas, D. 1979: Phytosociological research of the vegetation of the delta of the river Evros (Ainision Delta). Thesis, Thessaloniki: 158 pp. (in Greek).

Babalonas, D. \& Papastergiadou, E. 1990: Ein halophiles Gesellschaftsrelikt in griechischen Binneland. Tuexenia 10: 115-120.

Babalonas, D., Sykora, K. \& Papastergiadou, E. 1995: Review of Plant communities from Greek dunes and salt marshes, a preliminary summarizing List II, Anali di Botanica 53: 110-117.

Barkman, J., Doing, H. \& Segal, S. 1964: Kritische Bemerkungen und Vorschläge zur quantitativen Vegetationanalyse. Acta Botanica Neerlandica 13: 394-419.

Biondi, E. 1998: Diversità fitocenotica degli ambienti costieri italiani. Boll. Mus. Civ. St. Nat. Venezia 49: 39-105.

Biondi, E., Allegrezza M. \& Filigheddu, R. 1990: Su alcune associazioni di vegetazione nitrofila della Sardegna settentrionale. Boll. Soc. Sarda Sci. Nat. 27: 221-236.

Biondi, E., Filigheddu R. \& Farris, E. 2001: Il paesaggio vegetale della Nurra (Sardegna nordoccidentale). Fitosociologia 38: 3-105.

Bondev, I. 1991: The vegetation of Bulgaria. Map in scale 1:600000 with explanatory text. Publ. House of Sofia University "St. Kliment Ochridsky". Sofia, 183 pp. (in Bulgarian).

Bondev, I., Ganchev, S. \& Kochev, H. 1964: Subtype Halophyte vegetation. In: Ganchev, I., Bondev, I. \& Ganchev, S. (eds.): Vegetation of meadows and pastures in Bulgaria, Sofia, BAS, pp. 237-239 (in Bulgarian).

Borhidi, A. 2003: Magayaroszág növénytársulásai. Budapest. $610 \mathrm{p}$.

Braun-Blanquet, J. 1951: Les Groupements Végétaux de la France Méditterranéenne. Centre National de la Recherche Scientifique (Service de la Carte des Groupements Végétaux) et Di- rection de la Carte des Groupements Végétaux de l'Afrique du Nord, $297 \mathrm{pp}$.

Braun-Blanquet, J. 1952: Les groupements végétaux de la France Méditerranéenne C.N.R.S., Paris, 297 pp.

Braun-Blanquet,J. 1964:Pflanzensoziologie. Grundzüge der Vegetationskunde. 3 Aufl. Springer Verlag, Wien-New York, 86 pp.

Dajić, Z. 1996: Ekološka studija halofitske zajednice Puccinellietum limosae (Rapcs) Wend., PhD Thesis, Biološki fakultet, Beograd.

Delipavlov, D., Cheshmedzhiev, I., Popova, M., Terziiski, D. \& Kovachev, I. 2003: Handbook for identification of the plants in Bulgaria. Univ. of Agriculture Publ. House, Plovdiv, 591 pp. (in Bulgarian).

Dierßen, K. 1996: Vegetation Nordeuropas. Eugen Ulmer Verlag, Stuttgart, 838 pp.

Donită, N., Ivan, D., Goldea, G., Popescu, A., Chifu, Th., Pauc-Comanescu, M., Mititelu, D. \& Boşcaiu, N. 1992: Vegeta ia României. Editura Technic Agricol, Bucure ti, 407 pp.

Donită, N., Popescu, A., Paucă-Comanescu, M., Mihăilescu, S. \& Biri , I. - A. 2005: Habitatele din România. Editura Technic Silvic , Bucure ti, 496 pp.

Ganchev, S. \& Kochev, H. 1962: La Vegetation Gazonnante de la Vallé de la R. Stoudena. Proc. Inst. of Botany, BAS, 9: 43-78. (in Bulgarian).

Ganchev, S., Kochev, H. \& Yordanov, D. 1971: The halophylic vegetation in Bulgaria. Proc. Inst. of Botany, BAS, 21: 5-48 (in Bulgarian).

Géhu, J. M. 1976: Approche phytosociologique synthetique de la végétation des vases salées du littoral atlantique Français (Synsystématique et Synchorologique). Colloques Phytosociologiques 4: 395-462.

Géhu, J. M., Biondi, E., Géhu-Franck, J. \& Costa, M. 1992: Interpretation phytosociologique actualisée de quelques végétations psammophiles et halophiles de Camargue. Colloques Phytosociologiques 19: 103-131.

Géhu, J. M., Roman, N.\& Boullet, V. 1994: Observations nouvelles sur la végétation des côtes de Roumanie au sud du Delta du Danube. Fitosociologia 27: 73-89.

Géhu, J. M., Costa, M., Scoppola, A., Biondi, E., Marchiori, S., Peris, J.B., Franck, J., Caniglia, G. \& Veri, L. 1984: Essai synsystématique et synchorologique sur les végétations littorales italiennes dans un but conservatoire. Documents phytosociologiques 8: 393-474.

Golub, V., Karpov, D., Sorokin, A. \& Nikolaichuk, L. 2005: Communities of the class Festuco-Puc- 
cinellietea Soó ex Vicherek 1973 on the territory of Eurasia. Rastitelnost Rossii 7: 59-75 (in Russian).

Golub, V. \& Mirkin, B. 1986: Grasslands of the lower Volga valley. Folia Geobotanica 21(4): 337-395.

Hennekens, S. M. \& Schaminée, J. H. J. 2001: TURBOVEG, a comprehensive data base management system for vegetation data. Journal of Vegetation Science 12: 589-591.

Hennekens, S. 1996: MEGATAB - a visual editor for phytosociological tables. Version 1.0. October 1996. Ulft. 11 p.

Hill, M. O. 1979: TWINSPAN - a FORTRAN program for arranging multivariate data in an ordered two-way table by classification of the individuals and attributes. Cornell University, Ithaca, NY.

Horvatić, S. 1934: Flora i vegetacija otoka Paga. Prir. istraz. Jugosl. Akad. znan. i umjetnosti 19: 116-372.

Ivan, D., Donită, N., Coldea, G., Sanda, V., Popescu, A., Chifu, T., Boscaiu, N., Mitetelu, D. \& Paucă-Comanescu, M. 1993: Vegetation potentielle de la Roumanie. Braun-Blanquetia 9, Camerino. 79 pp.

Jalas, J. \& Suominen, J. (eds.) 1988: Atlas Florae Europaeae. Distribution of Vascular Plants in Europe. 3. Caryophyllaceae. Cambridge University Press, Cambridge. 416 pp.

Kaligarič, M. \& Škornik, S. 2006: Halophile vegetation of the Slovenian seacoast: Thero-Salicornietea and Spartinetea maritimae. Hacquetia 5 (1): 25-36.

Kochev, H. \& Yordanov, D. 1981: Vegetation of water basins in Bulgaria. Ecology, conservation and ecomonic importance. BAS.183 p. (in Bulgarian).

Korotkov, K., Morozova, O. \& Belonovskaja, E. 1991: The USSR vegetation syntaxa prodromus. Gregory Vilchek Publ., Moscow. 346 p.

Korzhenevsky, V. \& Klyukin, A. 1991: Vegetation description of mud volcanoes of Crimea. Feddes Repertorium 102 (1-2): 137-150.

Ladero, M., Navarro, F., Valle, C. J., Marcos, B., Ruiz-Tillez, T. \& Santos, M. 1984: Vegetacion de los saladares castellano-leoneses. Studia Botanica 3: 17-62.

Meshinev, T., Apostolova, I., Georgiev, V., Dimitrov, V., Petrova, A. \& Veen, P. 2005: Grasslands of Bulgaria. Final report on the National Grasslands Inventory Project - Bulgaria, 2001-2004. Dragon 2003 Ltd. Publishers, Sofia.104 p.
Micevski, K. 1965: Halofitska vegetacija Ovčeg polja. Acta Mus. Maced. Sci. Nat. Skopje 10: 6790.

Molinier, R. 1934: Études phytosociologiques et écologiques en Provence occidentale. PhD Thesis, Université de Marseille, 273 pp.

Mucina, L. 1993: Puccinellio-Salicornietea. In: Mucina, L., Grabherr, G. \& Ellmauer, T. (eds.): Die Pflanzengesellschaften Österreichs. Teil 1, Anthropogene Vegetation, 522-549.

Ninov, N. 1998: A new FAO-based taxonomic list of soils in Bulgaria and of the plant communities of them. Phytologia Balcanica 4 (1-2): 223236.

Ninov, N. 2002: Soils. In: Kopralev, I. (ed.): Geography of Bulgaria. ForCom, Sofia, pp. 277-315 (in Bulgarian).

Pop, I. 2002. Vegetatia solurilor saraturoase din Romania. Contributii Botanicae 35 (2): 285328

Pott, R. (1997): Die Pflanzengesellschaften Deutschlands. Verlag Eugen Ulmer Stuttgart. 622 pp.

Rodwell, J., Schamnée, J., Mucina, L., Pignatti, S., Dring, J. \& Moos, D. 2002: The Diversity of European Vegetation. An overview of phytosociological alliances and their relationships to EUNIS habitats. Landbouw, natuurbeheer en visserij. Wageningen. 168 pp.

Sanda, V., Popescu, A. \& Arcuş, M. 1999: Revizia critică a cominităţilor de plante din România. Constanța, TPI. 143 pp.

Şerbănescu, I. 1965: Asociațiile halophile din Câmpia Română. Com. Geol. Studii tehnice şi econ. Seria C. Pedol., Buc., 15: 1-149.

Stefanoff, B. 1943: Phytogeographishe Elemente in Bulgarien. Proc. of Bull. Acad. Sci. 39, 506 pp. (in Bulgarian).

Stoyanoff, N. 1941: Versuch einer phytozoenologishen Charakteristik Bulgariens. Ann. Univ. Sofia, Fac. Physico-Matematique 34(3): 93-184. (in Bulgarian).

Stoyanoff, N. 1948: Die Vegetation unserer Donauinsel und ihre Bewirtschaftung. BAS, Sofia. 187 pp. (in Bulgarian).

Țopa, E. 1939: Vegetația halofitelor din nordul României in legătură cu cea din restul țărill. Bul. Fac. Şt. Cernăți, 13: 1-79.

Tzonev, R. 2002: Flora and vegetation of the Middle Danube plain between the valleys of Vit and Stoudena Rivers. PhD Thesis. Sofia University "St. Kliment Ochridsky". 166 pp. (in Bulgarian). 
Tzonev, R. in press.: Plant communities, habitats and ecological changes in the vegetation on the territory of three protected areas along the Danube River. - In: Ivanova, D. (ed.). Proceedings of the IVth Balkan Botanical Congress, BAS, Sofia.

Tzonev, R., Roussakova, V. \& Dimitrov, M. 2006: The Western-Pontic steppe vegetation in Bulgaria. Hacquetia 5 (1): 5-23.

Velchev, V. (ed.) 1984: Red Data Book of the People's Republic of Bulgaria. Vol. 1. Plants. BAS, Sofia, 446 pp. (in Bulgarian).

Velev, S. 1990: The Climate of Bulgaria. Narodna Prosveta Publ. House, Sofia, 179 pp. (in Bulgarian).

Vicherek, I. 1973: Die Pflazengesellschaften der Halophyten- und Subhalophytenvegetation der Tschechoslowakei. Vegetace ČSSR, Ser. A, 5: 1-200.

Vural, M., Ekim, T., Duman, H., Aytaz, Z. \& Adigozel, N. 1999: Vegetation and flora of the Konya Closed Basin. Biodiversity Programme
Report No 12. Doğal Hayatı Koruma DerneğiGazi Universitesi, İstanbul, 102 p.

Weber, H. E., Moravec, J. \& Theurillat, J.-P. 2000: International Code of Phytosociological Nomenclature. 3rd edition. Journal of Vegetation Science 11: 739-768.

Westhoff, V. \& van der Maarel, E. 1978: The BraunBlanquet approach. In: Whittaker, R.H. (ed.): Classification of plant communities. Junk, The Hague, pp. 287-399.

Yordanov, D. 1931: Pflanzengeographische Studien der Sümpfe Bulgariens in ihrer Beziehung zur höheren Vegetation. I Teil - Binnensümpfe. Ann. Univ. Sofia, Fac. Phys.-Math. 27(3): 75-156 (in Bulgarian).

Yordanov, D. \& Kuzmanov, B. 1966: Chenopodiaceae. In: Yordanov, D. Flora Republicae Popularis Bulgaricae, Vol. 3. In Aed. Acad. Sci. Bulg., Sofia, pp. 521-575 (in Bulgarian).

Zohary, M. 1973: Geobotanical foundations of the Middle East. Vol.1, Gustav Fischer Verlag, Stuttgart, $340 \mathrm{pp}$. 


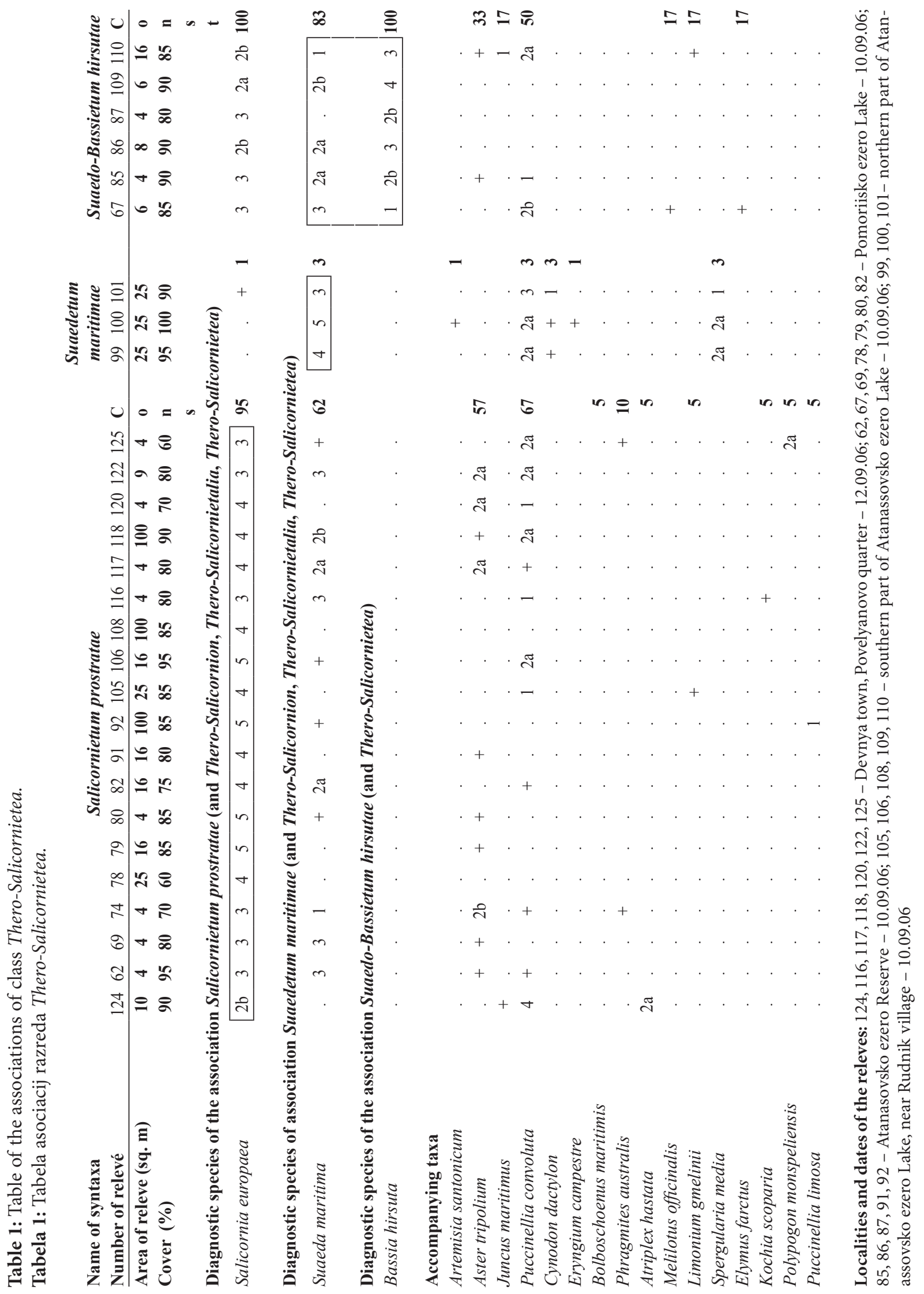


Table 2: Table of the associations Juncetum maritimae, Petrosimonio brachiatae-Puccinellietum, Aeluropetum littoralis, Crypsidetum aculeatae, Heleochloetum alopecuroides convolutae.

Table 2: Tabela asociacij Juncetum maritimae, Petrosimonio brachiatae-Puccinellietum, Aeluropetum littoralis, Crypsidetum aculeatae, Heleochloetum alopecuroides convolutae.

\begin{tabular}{|c|c|c|c|c|c|c|c|c|c|c|c|c|c|}
\hline \multirow[b]{3}{*}{ Number } & \multicolumn{6}{|c|}{ Petrosimonio brachiatae-Puccinellietum convolutae } & \multicolumn{7}{|c|}{ Heleochloetum alopecuroides } \\
\hline & $\begin{array}{l}\text { Juncetum } \\
\text { maritimae }\end{array}$ & & & $\begin{array}{l}\text { luro } \\
\text { litor }\end{array}$ & $\begin{array}{l}\text { petu } \\
\text { alis }\end{array}$ & & & $\begin{array}{l}\text { rypsi } \\
\text { acule }\end{array}$ & $\begin{array}{l}\text { detu } \\
\text { eatae }\end{array}$ & & & & \\
\hline & 109112120 & $\begin{array}{lll}91 \quad 92 & 106 \\
\end{array}$ & 59 & 62 & 64 & $69 \mathrm{a}$ & 12 & 100 & 33 & 35 & 40 & 98 & 31 \\
\hline Area of relevé (sq. m) & $25 \quad 100100$ & $\begin{array}{lll}16 & 16 & 16\end{array}$ & 2 & 2 & 4 & 10 & 10 & 2 & 10 & 4 & 16 & 4 & 25 \\
\hline Cover $(\%)$ & $100100 \quad 95$ & $100 \quad 100 \quad 90$ & 30 & 50 & 60 & 50 & 30 & 80 & 30 & 60 & 80 & 90 & 50 \\
\hline
\end{tabular}

Diagnostic taxa of association Juncetum maritimi

Juncus maritimus

\begin{tabular}{|lll|l|}
\hline 4 & 5 & 5 & 3 \\
\hline
\end{tabular}

Diagnostic taxa of association Aeluropetum littoralis (and Juncetea maritimi)

Aeluropus littoralis

\begin{tabular}{|lll|l|}
\hline 4 & 3 & 3 & 3 \\
\hline
\end{tabular}

Diagnostic taxa of association Petrosimonio brachiatae-Puccinellietum convolutae ass. nova

Petrosimonia brachiata

(Dt of Festuco-Puccinellietea)

Puccinellia convoluta

Artemisia santonicum

(Dt of Festuco-Puccinellietea)

Aster tripolium (Dt of Juncetea maritimi)

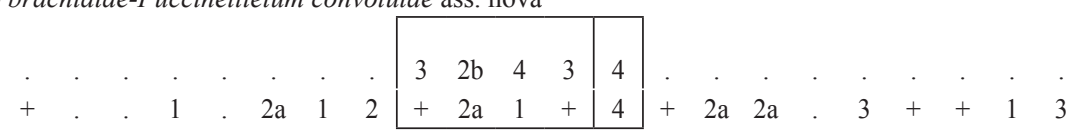

Diagnostic taxa of association Crypsidetum aculeatae (and Crypsietea aculeatae)

Crypsis aculeata

\begin{tabular}{|llll|l|}
3 & 3 & 4 & 4 & 4 \\
\hline
\end{tabular}

Diagnostic taxa of association Heleochloetum alopecuroidis (and Crypsietea aculeatae)

Crypsis alopecuroides

$2 \mathrm{~b}$

\begin{tabular}{|lll|l|}
\hline 4 & 3 & 4 & 3 \\
\hline
\end{tabular}

Diagnostic species of higher units

Juncetea maritimi, Juncetalia maritimi, Juncion maritimi

Bolboschoenus maritimis

Limonium vulgare

Diagnostic species of higher units

Festuco-Puccinellietea, Puccinellietalia, Puccinellion limosae

Puccinellia limosa

Taraxacum bessarabicum

Accompanying taxa

Salicornia europaea

Cynodon dactylon

Suaeda maritima

Polygonum pulchellum

Atriplex tatarica

Hordeum hystrix

Phragmites australis

Echinochloa crus-galli

Puccinellia distans

Lepidium ruderale

Juncus gerardii

Scorzonera laciniata

Localities and dates of the releves: 109, 112, 106 - Atanassovsko Ezero Lake (southern part) (Burgas district) - 10.09.06; 120 - Devnya town, Povelyanovo quarter (Varna district) - 12.09.06; 91, 92 - Atanassovsko Ezero Reserve - 10.09.06; 59, 62, 64, 69a - Pomoriisko Ezero Lake - 10.09.06; 12 - Radetski village (Stara Zagora district) - 8.09.06; 100, 98 - Rudnik village (north from Atanassovsko ezero) - 10.09.06; 31, 33, 35, 40 - Blatec village (Sliven district) - 9.09.06 
Table 3: Association Diantho pallidiflori-Puccinellietum convolutae ass. nova.

Tabela 3: Asociacija Diantho pallidiflori-Puccinellietum convolutae ass. nova.

Number of relevé

Area of releve (sq. m)

Cover $(\%)$

\begin{tabular}{|c|c|c|c|c|c|c|c|c|c|c|c|c|c|c|c|c|c|c|c|c|c|c|c|c|c|c|}
\hline 1 & 2 & 3 & 4 & 5 & & & 7 & 8 & 1 & & & 13 & 14 & 1 & & & & 48 & 5 & 5 & & & & & & \\
\hline 25 & 25 & 25 & 25 & 25 & 1 & & 25 & 25 & 2 & & & 25 & 25 & 2 & & & 6 & 9 & 9 & & & & & & & \\
\hline 90 & 100 & 100 & 95 & 10 & & & 00 & 95 & 6 & & & 70 & 90 & 10 & & & 5 & 40 & 2 & & & & & & & \\
\hline 1 & 1 & 4 & $2 a$ & 1 & & & 1 & $2 a$ & 1 & & & & . & & & & + & 1 & 2 & & & & & & & \\
\hline 1 & 3 & . & . & . & & & . & 4 & 4 & & & 4 & 5 & 5 & & & . & $\sigma^{\prime}$ & . & 2 & & & & & & \\
\hline $2 b$ & $2 a$ & $2 a$ & $2 b$ & . & & & $2 b$ & $2 a$ & 2 & & & . & . & & & & . & 1 & . & & & & & & & \\
\hline 3 & $2 a$ & 1 & 3 & . & & & + & 1 & $t$ & & & . & . & & & & . & . & 1 & & & & & & & \\
\hline $2 a$ & $2 a$ & $2 b$ & $2 \mathrm{a}$ & . & & & $2 \mathrm{a}$ & . & . & & & . & . & 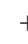 & & & . & . & . & 2 & & & & & & \\
\hline . & + & . & $2 \mathrm{a}$ & . & & & 1 & + & & & & . & . & - & & & . & . & . & & & & & & & \\
\hline . & . & . & . & + & & & . & + & 2 & & & + & . & & & & . & & . & & & & & & & \\
\hline
\end{tabular}

Diagnostic species of the association Diantho pallidiflori-Puccinellietum convolutae ass. nova

Puccinellia convoluta

Elymus elongatus

Polygonum pulchellum

Limonium vulgare subsp. serotinum

Dianthus campestris ssp. pallidiflorus

Scilla autumnalis

Centaurium spicatum

Diagnostic species of higher units Festuco-Puccinellietea, Puccinellietalia, Puccinellion limosae

Lotus tenuis

Artemisia santonicum

Juncus gerardii

Camphorosma monspeliaca

Crypsis aculeata

$\begin{array}{cccccccc}\cdot & 1 & \cdot & 1 & . & . & 1 & \text { II } \\ . & . & + & . & 2 a & . & . & \text { II } \\ . & . & . & . & . & + & 2 a & \text { II } \\ 1 & 3 & 2 a & 2 a & . & . & . & \text { II } \\ . & + & 2 a & 2 b & . & . & . & \text { I }\end{array}$

Accompanying taxa

Cynodon dactylon
Plantago lanceolata
Hordeum hystrix
Cichoryum inthybus
Lactuca saligna
Taeniatherum caput-medusae
Atriplex tatarica
Bupleurum tenuissimum
Eryngium campestre
Spergularia marina
Achillea millefolium gr.
Bromus tectorum
Centaurea calcitrapa
Pyrus communis
Verbascum blattaria
Scorzonera laciniata
Allium sp.
Plantago major var. uliginosum
Xanthium strumarium
Aster tripolium
Suaeda maritima
Atriplex hastata
Bromus arvensis
Mentha pulegium
Portulaca oleracea
Pulicaria dysenterica
Conyza canadensis
Elymus farctus

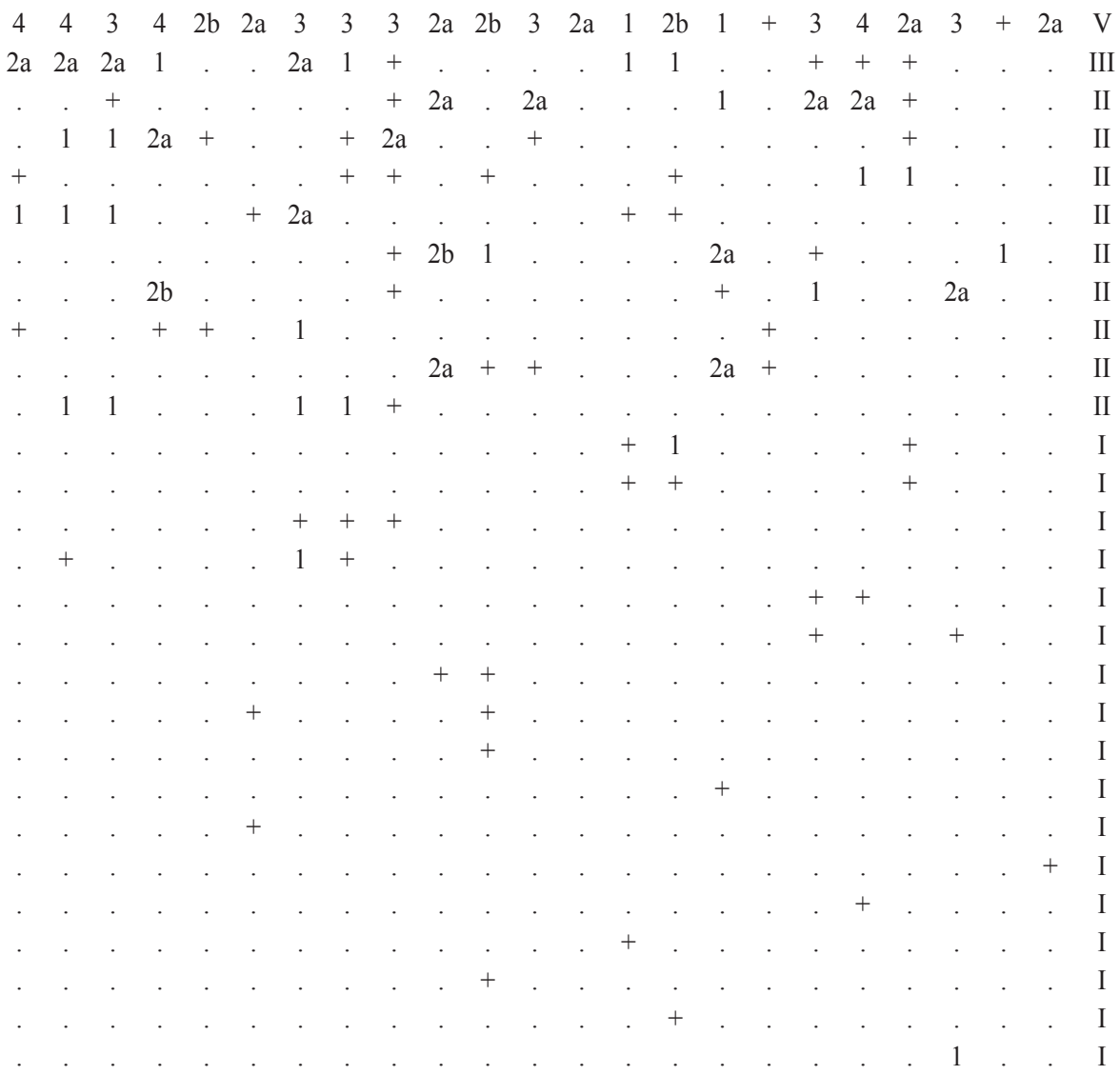


Lolium perenne

Teucrium scordium

Trifolium fragiferum ssp.

bonannii

Verbena officinalis

Carex sp.

Centaurea solstitialis

Cephalaria transilvanica

Chrysopogon gryllus

Colchicum autumnale

Crepis setosa ssp. rhoedifolia

Cirsium vulgare

Dichantium ischaemum

Filago vulgaris

Herniaria hirsuta

Inula britanica

Nigella arvensis

Phleum arvense

Salvia virgata

Trifolium campestre

Localities and dates of the releves: $1,2,3,4,5,6,7,8,10$ - Radnevo town (Stara Zagora district) - 8.09.06; 11, 13, 14 - Radetski village (Stara Zagora district) - 8.09.06; 17 - Kunevo village (Stara Zagora district) - 8.09.06; 45, 46 - Trapoklovo village (Sliven district) - 9.09.06; 48, 50 Atolovo village (Yambol district) - 9.09.06; 54, 55, 57, 58 - Sigmen village (Burgas district) - 9.09.06; 95, 101 - Rudnik village (north from Atanassovsko ezero Reserve) - 10.09.06. 
Table 4: The associations Bupleuro-Camphorosmetum monspeliacae and Camphorosmetum annuae.

Table 4: Asociaciji Bupleuro-Camphorosmetum monspeliacae in Camphorosmetum annuae.

Number of relevé

$\begin{array}{llllllllllllllllllll}20 & 21 & 22 & 23 & 24 & 25 & 26 & 28 & 30 & 36 & 37 & 39 & 41 * & 42 & 43 & 51 & 52 & 53 & 56 & 94\end{array}$

Area of relevé (sq. m)

$\begin{array}{lllll}32 & 34 & 130 & 131 & 132\end{array}$

Cover $(\%)$

$\begin{array}{llllllllllllllllllll}70 & 25 & 80 & 70 & 60 & 60 & 70 & 70 & 70 & 90 & 50 & 70 & 90 & 80 & 70 & 70 & 80 & 90 & 70 & 60\end{array}$

$\begin{array}{lllll}60 & 80 & 70 & 60 & 50\end{array}$

Diagnostic taxa of the association

\begin{tabular}{|lccccccccccccccccccccccccccccc}
\hline Camphorosma monspeliaca & 4 & 4 & 4 & 4 & 4 & 3 & 4 & $2 \mathrm{~b}$ & $2 \mathrm{~b}$ & 3 & 3 & 3 & 3 & 4 & 3 & 3 & 3 & 3 & 3 & 3 & $\mathrm{~V}$ &. &. &. &. &. \\
Puccinellia convoluta &. &. &. &. & $2 \mathrm{a}$ & 3 & + & 3 & $2 \mathrm{a}$ & $2 \mathrm{a}$ & $2 \mathrm{a}$ &. & 1 & $2 \mathrm{~b}$ & $2 \mathrm{~b}$ & $2 \mathrm{a}$ & 3 & $2 \mathrm{~b}$ & 3 &. & $\mathrm{IV}$ & 1 & + & 2 & 2 & 1 \\
Cynodon dactylon &. &. & 1 & + & 1 & $2 \mathrm{a}$ &. & + & 1 & $2 \mathrm{~b}$ & $2 \mathrm{a}$ & $2 \mathrm{a}$ & $2 \mathrm{~b}$ & $2 \mathrm{a}$ & $2 \mathrm{a}$ & $2 \mathrm{a}$ & $2 \mathrm{a}$ & $2 \mathrm{a}$ & $2 \mathrm{~b}$ & $2 \mathrm{~b}$ & $\mathrm{~V}$ &. &. & 1 &. &. \\
Bupleurum tenuissimum & + &. & & + &. &. & + &. & + &. &. &. & + &. & + & 1 &. &. &. &. & 1 & + & + & $\mathrm{III}$ &. &. &. &. &. \\
\hline
\end{tabular}

Camphorosma annua

Diagnostic species of higher units Festuco-Puccinellietea, Puccinellietalia, Puccinellion limosae

Taraxacum bessarabicum

Puccinellia limosa

Crypsis aculeata

Pholiurus panonnicus

Plantago cornuti

Accompanying taxa

Plantago lanceolata

Polygonum pulchellum

Elymus elongatus

Atriplex tatarica

Hordeum hystrix

Limonium vulgare ssp. serotinum

Dianthus campestris ssp. pallidiflorus

Eryngium campestre

Scilla autumnalis

Spergularia marina

Taeniatherum caput-medusae

Atriplex hastata

Bromus tectorum

Puccinellia distans

Achillea millefolium gr.

Lepidium ruderale

Bromus arvensis

Scorzonera laciniata

Allium sp.

Polygonum arenastrum

Bromus scoparius

Portulaca oleracea

Heliotropium supinum

Lolium perenne

Centaurea diffusa

Gypsophila muralis

Hypochaeris maculata

Lepidium campestre

Tragus racemosus

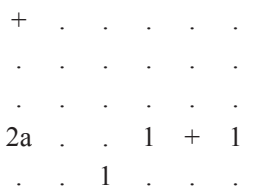

Localities and dates of the releves: 20, 21, 22, 23, 24 - Bikovo village (Sliven district), 8.09.06; 25, 26, 28, 30 - Zhelyu voivoda village (Sliven district), 9.09.06; 32, 34, 36, 37, 39, 41, 42 - Blatec village (Sliven district), 9.09.06; 130, 131, 132 - Blatec village (Sliven district), 4.09.2008; 43 - Trapoklovo village (Sliven district), 9.09.06; 51, 52 - Atolovo village (Yambol district), 9.09.06; 53, 56 - Sigmen village (Burgas district), 9.09.06; 94 - north from Atanassovsko ezero Reserve - 10.09.06 (Burgas district) 
Table 5: Communities of Artemisia santonicum.

Tabela 5: Združbe z vrsto Artemisia santonicum.

Number of relevé

Area of relevé (sq. m)

\begin{tabular}{ccccccccccc}
66 & 68 & 70 & 74 & 80 & 84 & 85 & 88 & 103 & 107 & $\mathrm{C}$ \\
\hline 4 & 16 & 25 & 16 & 16 & 4 & 4 & 16 & 25 & 25 & 0
\end{tabular}

Cover $(\%)$ $\begin{array}{lllllllllll}85 & 85 & 70 & 90 & 85 & 90 & 80 & 80 & 100 & 100 & \mathrm{n}\end{array}$

Dominant species (Dt Festuco-Puccinellietea)

Artemisia santonicum

\begin{tabular}{|c|c|c|c|c|c|c|c|c|c|}
\hline 4 & 3 & 4 & 5 & 5 & 5 & 5 & 4 & 5 & 4 \\
\hline
\end{tabular}

Diagnostic species of higher units Festuco-Puccinellietea, Puccinellietalia, Puccinellion limosae

Petrosimonia brachiata

. $2 \mathrm{~b} .2 \mathrm{a} . \quad . \quad . \quad \mathrm{I}$

Accompanying taxa

Puccinellia convoluta

Elymus elongatus

Atriplex tatarica

Melilotus officinalis

Bromus arvensis

Salicornia europaea

Polygonum pulchellum

Lactuca saligna

Phragmites australis

Salsola soda

Cerastium dubium

Lepidium perfoliatum

Tortula sp.

Localities and dates of the releves: $66,68,70,74,80$ - Pomoriisko ezero Lake - 10.09.06; 84, 85, 88 Atanasovsko ezero Reserve - 10.09.06; 103, 107 - Atanassovsko ezero (southern part) Lake - 10.09.06 